\title{
Early-Middle Ordovician Seascapescale aggregation pattern of sponge-rich reefs across the Laurentia paleocontinent
}

\section{Kröger, Björn}

2020-12-28

Kröger , B \& Penny , A 2020 , ' Early-Middle Ordovician Seascapescale aggregation pattern of sponge-rich reefs across the Laurentia paleocontinent ' , Palaios , vol. 35 , no. 12 , pp. 524-542 . https://doi.org/10.2110/palo.2020.039

http://hdl.handle.net/10138/326095

https://doi.org/10.2110/palo.2020.039

unspecified

acceptedVersion

Downloaded from Helda, University of Helsinki institutional repository.

This is an electronic reprint of the original article.

This reprint may differ from the original in pagination and typographic detail.

Please cite the original version. 


\section{RRH: ORDOVICIAN REEF SEASCAPE AGGREGATION PATTERN}

LRH: B.K. KRÖGER and A. PENNY

Research Article

DOI: http://dx.doi.org/10.2110/palo.2020.039

EARLY-MIDDLE ORDOVICIAN SEASCAPE-SCALE AGGREGATION PATTERN OF SPONGE-RICH REEFS ACROSS THE LAURENTIA PALEOCONTINENT BJÖRN KRÖGER and AMELIA PENNY

University of Helsinki, Finnish Museum of Natural History, 00560 Helsinki, Finland email: bjorn.kroger@helsinki.fi

ABSTRACT: During the late Cambrian-Early Ordovician interval the predominant non-microbial reef builders were sponges or sponge-like metazoans. The lithological and faunal composition of Cambro-Ordovician sponge-dominated reefs have previously been analyzed and reviewed. Here we take the relationship between reef aggregation pattern at reef to seascape scale into account, and look for changes during the Early-Middle Ordovician interval, in which metazoans became dominant reef builders. In a comparison of sponge-rich reefs from eight sites of the Laurentia paleocontinent three different seascape level reef growth patterns can be distinguished: (1) mosaic mode of reef growth, where reefs form a complex spatial mosaic dependent on hard substrate; (2) episodic mode, where patch reefs grew exclusively in distinct unconformity bounded horizons within non-reefal lithological units that have a much larger thickness; and (3) belt-and-bank mode, where reefs and reef complexes grew vertically and laterally as dispersed patches largely independent from truncation surfaces. The distinct modes of growth likely represent specific reef forming paleocommunities, because they differ in content and abundance of skeletal metazoan framebuilders, bioturbation intensity of non-skeletal reef sediment matrix, and in association of reef growth with underlying hard substrate. We suggest, based on a review of Laurentian reef occurrences, that the mosaic mode dominated in Early Ordovician strata and that the dominance shifted toward the belt and bank mode from Middle Ordovician strata onward.

INTRODUCTION

Over a period of more than 60 million years, during the late Cambrian-Middle Ordovician, the predominant global non-microbial reef builders were sponges or sponge-like metazoans. Following the demise of archaeocyaths at the end of the Terreneuvian and prior to the Darriwilian epoch sponges (keratose-types, chaetetids, and lithistids) and sponge-like pulchrilaminids and calathids aggregated in shallow marine carbonate depositional environments into clusters and patches to form bioherms and biostromes (Toomey and Nitecki 1979; Alberstad and Repetski 1989; Lee and Riding 2018). This interval is only one of several geo-historical episodes of sponge dominance in reef building during the Phanerozoic eon (Brunton and Dixon 1994).

The lithological composition of sponge-rich Cambro-Ordovician sediments has been described in numerous publications (e.g., Toomey and Nitecki 1979; Klappa and James 1980; Pratt and James 1982; Canas and Carrera 1993; Adachi et al. 2009; Lee et al. 2014, 2019). Detailed reconstructions of the reef forming ecological consortia and processes exist (e.g., Hong et al. 2015; Shen and Neuweiler 2018). In recent years, additionally, major reviews were published, analyzing large scale evolutionary trends of faunal compositions of Cambro-Ordovician sponge-dominated reefs, and their possible underlying controls (Hong et al. 2015; Lee and Riding 2018).

One aspect, crucial to the aggregative growth of sessile skeletal benthos in general, is missing in almost all of these previous analyses. None of the earlier analyses has evaluated the relationship between intra-reef spatio-temporal aggregation pattern and aggregation at seascape scale (hundreds of meters and kilometers) although, potentially, ecological change could affect all spatial and temporal levels of reef growth. A unified perspective is needed to determine changes of reef composition and aggregation pattern, because changes are interdependent at various spatiotemporal scales ranging from microfacies to seascape level, and from tidal to plate tectonic timescales.

The difficulties and obstacles of such an approach are numerous. Data for analysis are not readily available from the literature and field work is time consuming and expensive. A common 
quantitative methodology is not established yet for fossil reefs, which impedes comparison of published datasets. Quantification methods however, are partly available from modern seascapes, (e.g., Hui et al. 2010; Pittman et al. 2011; Wedding et al. 2011), and pattern analyses of spatial distributions across scales exist from fossil localities and sedimentary patches in marine carbonate environments (Purkis et al. 2007; Purkis and Kohler 2008; Plotnick 2017). These previous analyses are encouraging for a further investigation of spatial pattern of fossil reefs.

Here we present a first quantitative comparison of spatio-temporal aggregation pattern across scales using Ordovician sponge dominated reef settings from the Laurentia paleocontinent, using new data from field work during 2018-2019. Our results demonstrate the potential of such an approach for future comparisons of aggregation style between fossil reef localities.

\section{METHODS}

This study focuses on Ordovician reefs from eight locations across the paleocontinent Laurentia: (1, 2) Green Head and Ship Cove, southern Port au Port Peninsula, Newfoundland, Canada, respectively; (3-5) the Pyramid section, section $\mathrm{H}$, and near section $\mathrm{J}$ of the Ibex area, Utah, USA; (6) Point Riche and Table Head, Northern Peninsula, Newfoundland, Canada; and (7, 8) Île du Fantôme and Île de la Fausse Passe within the Mingan Archipelago National Park Reserve, Quebec, Canada, respectively (Fig.1). The reef locations have a stratigraphic age spanning the TremadocianDarriwilian epochs and represent in each case, a relatively short ranging, well constrained, depositional interval (Fig. 2). All eight reef localities occur in a geological and tectonic setting that has no post-depositional effect on the relative spatial reef distributions at the scale analyzed herein (see below).

We recorded the locations of reefs at sites 3 to 8 by holding a Garmin etrex 30x GPS unit with a location accuracy of $3 \mathrm{~m}$ over the center of each reef and recording a waymark. Individual reef centers could not be recorded at Green Head and Ship Cove because at these locations the reefs form expansive coalescent sheets that partly extent across the entire outcrop areas of more than 100 $\mathrm{m}$. Point counts were used to measure reef composition, and reef thickness and diameter were measured, following the procedures described by Kröger et al. (2017a) and Penny et al. (2020). We used morphotaxa and macroscopically visible lithological and sedimentary characters to distinguish categories for point counts, such as wackestone matrix, mudstone matrix, lithistid sponge, and encrusting bryozoan (see also Penny et al. 2020).

Data were analyzed using R statistical software, version 3.6.3 (R Core Team 2020) (reef coordinates and R-code for this analysis are available at https://doi.org/10.5281/zenodo.4274632). The spatial distribution of the reef coordinates at each locality can be expressed and a vector of the Euclidean distance from each reef to its nearest neighbor (our nndist) can be computed. The degree to which the observed distribution of nndist departs from a random distribution can be measured with the aggregation index R of Clark and Evans (1954). The Clark and Evans aggregation index gives the ratio of the observed mean nearest neighbor distance in the pattern to that expected for a Poisson point process of the same intensity. A value of $\mathrm{R}>1$ suggests ordering, while $\mathrm{R}<1$ suggests clustering of the coordinates. We used the aggregation index $\mathrm{R}$ to describe the distribution of the reef coordinates because it is consistent with our method to compare distances between reefs and it gives a quantitative measure of reef dispersal. Furthermore, we consider a method based on nearest neighbor distributions, such as the aggregation index $\mathrm{R}$, to be suitable for the spatial distributions of reefs in this study, which in several locations came from very narrow outcrop bands (see below). R was computed with a Kaplan-Meier type edge correction (Cumulative Distribution Function method), using the function clarkevans() of the R package "spatstat" version 1.61-0 (Baddeley and Turner 2005). Additionally, we standardized the observation window at each location to a randomly chosen $5 \mathrm{~m}$ wide band, because exposure varies strongly between locations, with some locations exposing reefs on a bedding surface up to $>50 \mathrm{~m}$ wide and several hundred meters long (locations 3, 7, 8; Fig. 3) and others exposing reefs on the same length along a narrow $10 \mathrm{~m}$ wide band following the strike of the reefal bed (locations 4, 5, 6; Fig. 3). The band was chosen from the full set of reef coordinates by the following procedure: (1) determine the reef in the extreme southwestern location edge ( reef $\left._{0}\right)$; (2) select all reefs within a $20 \mathrm{~m}$ distance around reef; 
(3) calculate the centroid of the selection (selectiono); (4) select all reefs within a $5 \mathrm{~m}$ distance around the centroid of selection, they are within the bandwidth of our sampling, this is bandwidthsample 0 ; (5) select a random reef from selectiono; (6) search for nearest neighbor reef of this random reef outside selection 0 , this is reef ${ }_{1}$, continue the routine $n$ times until the extreme northwestern edge of the location is reached with reef $\mathrm{n}_{\mathrm{n}}$ and collect bandwidth-sampleso-n; (7) calculate nndist and $\mathrm{R}$ with edge correction from the combined bandwidth-sample ${ }_{\mathrm{o}-\mathrm{n}}$. We repeated this procedure 100 times and calculated the mean $R$ and nndist for each of the 100 resulting $5 \mathrm{~m}$ bands. The $\mathrm{R}$ values resulting from this subsampling method are consistently smaller than the $\mathrm{R}$ values with edge correction only (Table 1). This is an effect of the subsampling and does not reflect the real spatial distributions, but it can identify a potential bias, introduced by very narrow reef outcrop areas. However, because the two measures are strongly linearly correlated (R-squared $=$ 0.994 , F-test p-value $<<0.001$ ), we conclude that this potential bias is not significant for the interpretation of our results.

To check whether the reefs were randomly spatially distributed, we performed a two-tailed test of clustering and dispersion using the clarkevans.test method with edge correction in spatstat, with the null hypothesis that the points are distributed similarly to complete spatial randomness (CSR). A p-value of $<0.05$ indicates a probability of less than $5 \%$ that the sample is similar to CSR and we can reject $\mathrm{H}_{0}$.

We calculated the coefficient of quartile variation (cqv) as a measure of relative dispersion of reef size of each location as $((\mathrm{q} 3-\mathrm{q} 1) /(\mathrm{q} 3+\mathrm{q} 1)) * 100$, where $\mathrm{q} 3$ and $\mathrm{q} 1$ are the third $(75$ th $\%)$ and first $(25$ th \%) quantiles of the nndist values of each locality, respectively. The dispersion of the reef sizes here is not to be confused with the spatial dispersion of reef sites analyzed with $\mathrm{R}$ and nndist. The higher the cqv, the greater the level of dispersion of reef sizes around the mean. The confidence intervals for cqv are calculated with the method of Bonett (2006) as implemented in the R Package "cvcqv" Version 1.0. The Bray-Curtis dissimilarity of the point counts per reef and per plot in a reef are our measures for lithological inter-reef heterogeneity.

GEOLOGICAL SETTING

Sponge-Rich Reefs of the Watts Bight Formation, Tremadocian, Newfoundland, Canada

The Watts Bight Formation, Skullrockian Regional Stage (Cordylodus lindstromi-

Cordylodus angulatus conodont zone), is exposed along the south coast of the Port au Port Peninsula, western Newfoundland. The formation comprises a 70-90 m thick cyclic succession of chert-rich, generally bioturbated carbonates (e.g., Knight and James 1987; Ji and Barnes 1994; Knight et al. 2008) and contains several horizons with thrombolitic and stromatolitic reefs. The formation is subdivided informally into a lower mound member, middle burrowed carbonategrainstone member, and an upper mound member representing two depositional sequences of an open subtidal-peritidal setting, with the middle member representing the shallowest part (Knight et al. 2008). Partly sponge-rich, predominantly thrombolitic reef complexes of the lower member are well exposed and accessible on a coastal section west of Ship Cove (48 $30^{\prime} 55.01 " \mathrm{~N}$, 58 59'33.16"W) (Boyce et al. 2011) and $20 \mathrm{~km}$ eastward at Green Head (48³2'45.69"N, 58 44'3.00"W) (Pratt and James 1982, 1986, 1989a; Knight et al. 2008).

Calathium Rich Patch Reefs of the Fillmore Formation, Tremadocian, Ibex Area, Utah, USA

The Fillmore Formation is a mixed siliciclastic and carbonate succession, which is exposed in a widespread area in the Confusion and House ranges, western Utah, USA. The Fillmore Formation is approximately $550 \mathrm{~m}$ thick, ranges from the Stairsian Regional Stage (Rossodus manitouensis conodont zone, Tremadocian) to the Blackhillsian regional Stage (Reutterodus andinus conodont zone, Floian) (Ross et al. 1997), and was divided into six informal members by Hintze $(1951,1953,1973)$. The formation consists of beds of shale, marl, siltstone, and burrow mottled limestone and contains abundant layers of flat pebble conglomerate. Four major reef horizons are known within the Fillmore Formation (e.g., Evans et al. 2003) of which two are dominated by calathids as major reef building organisms. The lower reef horizon, known as Church's reef interval (Evans et al. 2003) (Fig. 4C), was described in detail by Church $(1974,1991)$ and occurs within the second member of the Fillmore Formation, within the Acodus deltatus- 
Oneotus costatus conodont zone, Stairsian Regional Stage, late Tremadocian. The upper calathidrich reefal interval is not named and occurs at the base of the uppermost member of the Fillmore Formation, within the Reutterodus andinus zone, Blackhillsian Regional Stage, late Floian in an area that spans a distance of $\sim 13 \mathrm{~km}$ (Church 1991). Easily accessible and laterally extensive outcrops of the Church's reef interval occur in the southern House Range in an area described as Amphitheater by Church (1991) and as Pyramid section by Hintze (1973), just north of US-highway $50\left(39^{\circ} 2^{\prime} 0.67^{\prime \prime} \mathrm{N}, 113^{\circ} 21^{\prime} 27.24^{\prime \prime} \mathrm{W}\right)$. The unnamed upper calathid reef interval is well exposed at section H of Hintze $(1951,1973)$ in the south-eastern Confusion Range $\left(38^{\circ} 50^{\prime} 35.772^{\prime \prime} \mathrm{N}, 113^{\circ} 27^{\prime}\right.$ 36.72"W).

Sponge-Rich Patch Reefs of Wah Wah Formation, Floian, Ibex Area, Utah, USA

The Wah Wah Formation directly overlies the Fillmore Formation and in lithology resembles the latter in comprising a cyclic succession of mixed carbonates and siltstone to shale with a thickness of $~ 79$ m (Hintze 1951, 1973; Ross et al. 1997; Evans et al. 2003). The Wah Wah Formation ranges into the lower Dapingian, Periodon flabellum/Tripodus leavis conodont zone (Ross et al. 1997). Two conspicuous $1.5 \mathrm{~m}$ and $3 \mathrm{~m}$ thick reef intervals, with reefs rich in lithistid sponges occur in the lower, late Floian part of the formation (at $\sim 27 \mathrm{~m}$ and $49 \mathrm{~m}$ above the formation base) at and near the formation type section in the Confusion Range, western Utah (section J, Hintze 1951, 1973). Approximately $0.5 \mathrm{~km}$ to the north of the type section the reef horizons are well exposed with dozens of individual reefs accessible $\left(38^{\circ} 51^{\prime} 50.03^{\prime \prime} \mathrm{N}\right.$, $\left.113^{\circ} 27^{\prime} 38.40^{\prime \prime} \mathrm{W}\right)$.

Sponge-Rich Reefs of the Table Point Formation, Darriwilian, Newfoundland, Canada

The Table Point Formation (Klappa et al. 1980), Darriwilian, is exposed along the western coast of the Northern Peninsula, western Newfoundland. The formation is of regionally variable thickness, ranging from $>100 \mathrm{~m}$ to $>300 \mathrm{~m}$ (Stenzel et al. 1990). The Table Point Formation is a deepening-up depositional succession with peritidal-shallow subtidal dolomitic fenestral mudstone to peloidal grainstone lithologies its base (Klappa et al. 1980; Ross and James 1987). The middle and upper parts of the formation consist predominantly of thick bedded to massive, bioturbated bioclastic wackestone to packstone, which is in part dolomitic and contains horizons rich in flint nodules. Sponge rich patch reefs occur in the middle part and are reported from at least two localities $\sim 38 \mathrm{~km}$ apart in south-north direction (Klappa et al. 1980; Klappa and James 1980; James and Klappa 1989). The southern locality is the coastal outcrop at Table Point $\sim 3 \mathrm{~km}$ north of Bellburns $\left(50^{\circ} 21^{\prime} 47.6^{\prime \prime} \mathrm{N}, 57^{\circ} 32^{\prime} 15.9^{\prime \prime} \mathrm{W}\right)$, and the northern locality is the coastal outcrop in the vicinity of the Point Riche Lighthouse at the southwestern edge of the Point Riche Peninsula $\left(50^{\circ} 41^{\prime} 54.7^{\prime \prime N}, 57^{\circ} 24^{\prime} 37.2^{\prime \prime} \mathrm{W}\right)$. Stratigraphically the reef horizons occur $\sim 100-120 \mathrm{~m}$ above the base of the formation (Klappa et al. 1980; Williams et al. 1987) which corresponds to the early Darriwilian Eoplacognathus variabilis conodont zone (unit A3 of Stouge 1984).

Reefs of the Mingan Formation, Darrwilian, Mingan Islands, Quebec, Canada

The Mingan Formation is a late Darriwilian succession of shallow marine strata reflecting a transgressive depositional sequence, which outcrops extensively in the Mingan Islands, Quebec, attaining a thickness of around $50 \mathrm{~m}$ (Desrochers and James 1988). The Mingan Formation can be divided into a lower and upper section, separated by a karstic surface called the intra-Mingan unconformity (Desrochers and James 1988; Penny et al. 2020). The upper part, where the reefs discussed in this study occur, consists of the Grande Pointe Member, whose broad-scale sedimentology is strongly influenced by the paleotopography of the underlying karst surface at lateral scales of 1-10 km. Paleotopography on the intra-Mingan unconformity reaches a local syndepositional relief of up to $20 \mathrm{~m}$ (Desrochers and James 1988). Consequently, the Grande Pointe Member is a laterally heterogeneous selection of subtidal facies reflecting deposition in lagoons, beaches, reefs, sand shoals and a low-energy open shelf (Desrochers and James 1988).

The reefs of the Grande Pointe Member comprise both isolated reefs and reef complexes, and outcrop on at least 12 islands in the Mingan Archipelago (Desrochers and James 1989). The reefs have a convex-up morphology, and circular to elliptical outlines, and range from $0.5-5 \mathrm{~m}$ across and $0.2-1.5 \mathrm{~m}$ thick, and at some localities aggregate to form reef complexes tens of meters 
in lateral extent and up to $6 \mathrm{~m}$ thick (Desrochers and James 1989) (Fig. 4H). The reefs typically consist of up to $60 \%$ skeletal wackestone or mudstone matrix, with the remainder volumetrically dominated by in situ reef-builders, predominantly tabulate corals and bryozoans as well as sponges, with scarcer stromatoporoids and Solenopora (Desrochers and James 1989; Kröger et al. 2017a). Lithistid demosponges of the Mingan Formation were described by Rigby and Desrochers (1995), and bryozoans by Bolton and Cuffey (2005). Sheet-like bryozoans and tabulate corals contributed to reef accretion through framework building, and sediment trapping and binding, constructing crypts at reef margins (Cuffey 2006; Kröger et al. 2017a). Even within the same reef complex, reefs can host highly dissimilar reef-building assemblages and are often dominated by a single taxon (Desrochers and James 1989; Penny et al. 2020). The composition of reefs at Île du Fantôme and Île de la Fausse Passe were recently described in great detail (Penny et al. 2020), and features of the reef core textures and accretion mechanisms have also been previously described by Kröger et al. (2017a).

RESULTS

Sponge-Rich Reefs of the Watts Bight Formation, Tremadocian, Newfoundland, Canada

The reef complex exposed at west of Ship Cove (Fig. 4A) has a total thickness of $\sim 10 \mathrm{~m}$ and is composed of a stacked succession of up to $2 \mathrm{~m}$ thick hemispherical coalescent to sheet-like or pancake-like individual bioherms, each having a lateral extent of up to tens of meters. A meter-thick bedded burrow-mottled limestone onlaps the bioherms on the northern edges of the outcrop area, suggesting a minimum SW/NE width of the complex of $\sim 100 \mathrm{~m}$ (see also Boyce et al. 2011). The complex is composed of at least four types of bioherms, each with a distinct lithology: (1) The most distinctive lithology at Ship Cove consists of a clotted, heavily dolomitized limestone with decimeter sized maze-like (sensu Lee et al. 2014) or maceriate (sensu Shapiro and Awramik 2006) dolomitized and/or silicified pattern. The origin of the pattern is difficult to determine at Ship Cove, because of heavy dolomitization, but probably is similar to that of Green Head (see below). In thin section we determined filamentose micritic (keratose sponge?) patches and Lichenaria, similar to Green Head. Lithology (1) forms sheet like wide bioherms with a thickness of up to $2 \mathrm{~m}$. (2) The most widespread lithology at Ship Cove consists of massive arborescent-digitate thrombolites, which are commonly $\sim 0.5 \mathrm{~m}$ wide and, which in the lower part of the complex, often coalesce to larger discoidal buildups and extended tabular bodies (Fig. 4A). Lithology (3) is composed of a massive mottled and burrowed thrombolite, and lithology (4) is composed of columnar stromatolites, $\sim 40 \mathrm{~mm}$ across, sometimes branching, often grading downwards into burrows. Stromatolite laminae may be dolomitized and stand out on weathered surfaces. Between columns are accumulations of biodetritic wackestone. Mollusks (gastropods and cephalopods) are common in all four lithologies (see also Boyce et al. 2011). Additionally, patches of individual buildups occur, which are up to several meters in diameter, and $<1.5 \mathrm{~m}$ in thickness that contain abundant spar-filled conical cavities. The conical cavities are in most cases positioned with their tip directed downward. Many have silicified and/or dolomitized areas encrusting internal walls and none have internal structures preserved. The cones are interpreted as remnants of archaeoscyphiid sponges (Pratt and James 1982; Boyce et al. 2011).

The reef complex exposed at Green Head (Fig. 4B) is positioned stratigraphically slightly higher up in the lower member of the Watts Bight Formation (Knight and James 1987; Pratt and James 1989a) and has a thickness of $\sim 16 \mathrm{~m}$ and an outcropping SW/NE expansion of $\sim 80 \mathrm{~m}$. The reef complex consists of a stacked succession of decimeter to $3 \mathrm{~m}$ thick discoidal coalescent to tabular or pancake-like individual buildups, each having a lateral extent of a few to tens of meters, and each is topped by a truncation surface (Fig. 5). We detected four principle buildup lithologies, three of them are dominated by thrombolitic boundstone and/or a mudstone-skeletal wackestone matrix (mostly trilobites, sponge spicules are abundant): Lithology (1) (Fig. 6A, 6C) is most widespread at Green Head and consists of a decimeter sized coalesced maze-like pattern with a mudstone/wackestone matrix ( $27 \%$ on average) with abundant filamentose (sponge) and fenestral (microbial) patches. The matrix is in several places penetrated by a 3D pattern of irregularly branched to mottled thrombolites (up to 26\%). The dominant maze-like pattern reflects preferential 
dolomitization and silicification, probably along a grumous microbially-interpreted microtexture or along sheets and masses of Renalcis (33\% in average). In some buildups Lichenaria forms an additional component of locally up to 5\% (Fig. 6B). Lithology (1) is equivalent to the combined thrombolite-Renalcis, thrombolite-Lichenaria-Renalcis, and the Renalcis-thrombolite boundstonetype of Pratt and James $(1982,1989)$. Lithology (2) forms massive layers of up to $1.5 \mathrm{~m}$ thick and consists exclusively of arborescent-digitate thrombolites. Lithology (3) forms individual buildups of several meters in diameter, up to $<1.5 \mathrm{~m}$ in thickness, and consists of $70-80 \%$ mudstone/wackestone matrix in which spar-filled conical cavities, with diameters $20-70 \mathrm{~mm}$ across, interpreted as remnants of archaeoscypiid sponges (see above), are common. Lithology (4) occurs in two distinctive decimeter-thick layers at the base of bioherms with maceriate lithologies in the upper part of the Green Head complex and is composed of digitate stromatolites, which form elongated, lamellae-like columns with widths of typically less then $50 \mathrm{~mm}$ and lengths of more than $150 \mathrm{~mm}$. The main inter-reef lithology is grainstone, composed of rounded limestone intraclasts with well-developed micritic envelopes.

In summary, the bioherms of the Watts Bight Formation are composed of stacked successions of hemispherical coalescent to sheet-like or tabular individual bioherms. Facies definition and fabrics identification (inclusive identification of sponges etc.) in the field can be challenging because of the locally heavy overprint of dolomitization. This dolomitization can obscure original compositional heterogeneity. Nevertheless, the recorded lithological heterogeneity of the Watts Bight bioherms is very high on inter-reef scale as well as on intra reef scale.

Distinctive types of reefs occur at small distance and within the different reef types the heterogeneity of patches is locally very high. Additionally, at below decimeter scale a high variety of original depositional environments existed representing a small scale original topographic and substrate differentiation (Pratt and James 1982).

Calathium-Rich Patch Reefs of the Fillmore Formation, Tremadocian, Ibex Area, Utah, USA

The lowermost Calathium rich reef horizon in the Fillmore Formation, known as Church's reef horizon (Evans et al. 2003) (Fig. 4C) occurs within the slope-forming shale-siltstone Member (SfssM) and has a thickness of only $\sim 1.5 \mathrm{~m}$ at $\sim 198-199 \mathrm{~m}$ above the base of the formation (Church 1974). The SfssM consists of meter scale cycles of shale grading upward into nodular lime-mudstone, calcareous siltstone and locally flat pebble conglomerate and skeletal (echinoderm and trilobite dominated) packstone/grainstone. The reefs occur in an interval with a concentration of three to four distinctive erosional surfaces. The lowermost of these surfaces (SF1) is the most prominent, cuts up to $0.5 \mathrm{~m}$ into an underlying burrow mottled shale and is overlain by a up to $1 \mathrm{~m}$ thick intraformational conglomerate with poorly sorted and rounded clasts of up to $0.25 \mathrm{~m}$ in diameter with a fining up tendency. The second and third erosional surfaces (SF2, SF3) cut with scalloped (karstic) but less pronounced relief into the underlying conglomerate (described as scours and ripples by Church 1974). These two erosional surfaces are the upper and lower boundaries of $0.3-0.5 \mathrm{~m}$ thick layers of intraformational conglomerate with intraclasts with predominantly 20-50 $\mathrm{mm}$ clast-sizes and a fining up tendency. Locally within these beds skeletal packstone/grainstone lenses occur and biostromal concentrations of calathids are common in the northern outcrop area (see also Church 1974). The reefs developed between SF2 and SF3. The uppermost erosional surface (SF4), which also has a scalloped relief, locally cuts into the reefs and merges with SF3. SF3 and SF4 are distinctively silicified and rusty colored. SF4 is overlain by approximately $1.5 \mathrm{~m}$ of thick shale.

The reefs of the Church's reef interval form distinctive elongated patches with a median width of $1.7 \mathrm{~m}(\mathrm{n}=24)$, a median length of $3 \mathrm{~m}(\mathrm{n}=11)$ and a median nearest neighbor distance of $10 \mathrm{~m}(\mathrm{n}$ $=35$ ) with generally a NE-SW direction of elongation and with an aggregation index $\mathrm{R}=0.458$. Our measurements of the inter-reef distances are in agreement with Church (1974). However, we could not confirm Church's (1974) descriptions of individual reef lengths of up to $30 \mathrm{~m}$ and his reconstruction of the reefal area as formed by individual rows or bars of reefs (Church 1974, textfig. 7). The maximum length of an individual reef measured in this study was $7 \mathrm{~m}$. We did not find any indication of lateral alignment of individual reefs but a spatial clustering along the outcrop line 
(the second lowest in our dataset, Table 1). Point counts $(n=4)$ indicate that the reefs of the Church's reef interval consist predominantly of a silty, skeletal (echinoderm ossicles, trilobite carapaces) burrowed wackestone (mean $=46 \%$ ), a dark colored mudstone $(38 \%)$, and of in situ skeletons of calathids (16\%). Thin section examination revealed that the mudstone in many places contains or is formed at or around abundant patches rich in calathids, and chaetetid and lithistid sponges (Fig. 7A).

The upper unnamed calathid reef interval ( $\mathrm{H}$ reef interval, herein) has a thickness of $\sim 15 \mathrm{~m}$ and occurs at around the boundary between the calcarenite and the Calathium calcisiltite member of the Fillmore Formation (Fig. 8). The interval consists of at least four reefal horizons, each embedded in a massive, cross-bedded echinoderm-rich skeletal packstone/grainstone bed. Three of these horizons are associated with under and/or overlying erosional surfaces. The lower two of the calathid-reef horizons contains only small, less than $1 \mathrm{~m}$ wide and less than $0.5 \mathrm{~m}$ high, patch reefs and calathid accumulations, with a density of $\sim 3$ reefs per $10 \mathrm{~m}$ (estimated from small outcrop area of $\sim 20 \mathrm{~m}$ ) (Fig. 4D). Rare calathid micro-reefs and isolated calathids occur in the $\mathrm{H}$ reef interval also within the siltstone beds and contain here decimeter thick lenses and channels of packstone/grainstone. The most massive calathid reef horizon is $\sim 4 \mathrm{~m}$ thick and forms at the base of the Calathium calcisiltite member a packstone/grainstone bed with a gradual transition at its base from underlying siltstone and with a top with a complex pattern of erosional surfaces and a related small scale facies mosaic (Fig. 9). The inter-reef facies varies from massive, cross bedded packstone/grainstone to wedges of siltstone.

The reefs, which are up to $4 \mathrm{~m}$ thick, are composed of an irregular mosaic of threedimensional amalgamations of smaller reefal subunits and commonly form patches with an average diameter of $\sim 2 \mathrm{~m}$ (median $=1.8 \mathrm{~m}$, mean $=2.1 \mathrm{~m}, \mathrm{n}=30$ ). The median nearest neighbor distance between the reefs is $4.4 \mathrm{~m}(\mathrm{n}=32)$ with an aggregation index $\mathrm{R}=0.487$. Point counts $(\mathrm{n}=11)$ result in a content of $75 \%$ of skeletal mudstone/wackestone reef matrix, $21 \%$ calathid skeletons, and $4 \%$ of a fenestral mudstone (Fig. 7D). All other components are rare, including vagrant skeletal benthos, such as trilobites and brachiopods. Thin sections reveal, that the matrix is composed of patches of a silty, burrowed skeletal (echinoderm ossicles, trilobites and brachiopod shell hash) wackestone, a fenestral mudstone/wackestone with abundant remains of chaetetid and lithistid sponges. The reefs of the lowermost reefal horizons in the $\mathrm{H}$ interval contains less abundant calathids and the matrix is dominated by a thrombolithic to fenestral mudstone/wackestone (Fig. 7C).

The uppermost reef horizon of the $\mathrm{H}$ reef interval is an approximately $1 \mathrm{~m}$ thick unconformity bounded layer with a laterally variable inter-reef facies with a packstone/grainstone, that locally contains a conspicuous brachiopod-trilobite coquina near the reefs and a flat pebble conglomerate at greater distance from the reef. The reefs of this upper interval are smaller in diameter, than compared with the underlying interval and in many places grew on the upper surface of the underlying reefs but otherwise do not differ in composition or spatial distribution from the directly underlying reefs.

In summary, the sponge rich bioherms of the Fillmore Formation occur in distinct horizons and form on average $\sim 1-2 \mathrm{~m}$ wide subcircular to oval patch reefs composed of masses sponge skeletons and calathids within a silty, burrowed mudstone/wackestone matrix. The compositional heterogeneity among of the reefs is generally very low, but within reefs, at decimeter scale and below, patches can differ in predominance of different types of sponges and matrix components. Sponge-Rich Patch Reefs of Wah Wah Formation, Floian, Ibex Area, Utah, USA

Two distinct reef horizons occur in the lower part of the Wah Wah Formation (Fig. 10). The Wah Wah Formation consists of several meter-thick cycles predominantly of calcareous siltstone and shale, which grade upward into nodular mudstone/wackestone containing lenses of intraclastic conglomerates and skeletal (mostly echinoderm ossicles and brachiopod shell hash) packstone/grainstone.

The reefs of the upper horizon occur in an interval with a concentration of erosional surfaces (Figs. 4F, 10). The lowermost erosional surface (SF1) cuts with a low relief of $\sim 0.1 \mathrm{~m}$ into a 
massive shale and is overlain by about $0.2 \mathrm{~m}$ thick cross bedded calcareous siltstone-sandstone with a surface formed of ripple marks. This siltstone-sandstone bed is overlain by $\sim 0.35 \mathrm{~m}$ of shale and 0.6-0.8 $\mathrm{m}$ of mudstone/wackestone which contains up to $\sim 50 \mathrm{~mm}$ thick meter-wide lenses and channels of intraclastic conglomerate and skeletal packstone/grainstone. Trilobites and mollusks are abundant and a single $\sim 3 \mathrm{~cm}$ wide questionable domal bryozoan colony has been identified within this layer, which is cut at its top by a prominent erosional surface. This second erosional surface (SF2) has a relief of $\sim 0.2 \mathrm{~m}$ and forms low $\sim 2 \mathrm{~m}$ wide ridges and channels. The $\sim 1.5 \mathrm{~m}$ thick reefs of the upper reef horizon directly develop on this surface. The reefs generally have a $<1 \mathrm{~m}$ wide talus of intraclastic conglomerate and skeletal packstone/wackestone. Locally the reef top forms a third erosional surface, cutting into the reef cores. The reefs are covered by a $\sim 1.5 \mathrm{~m}$ thick siltstone. In both reef horizons the reefs form distinct elongated patches with a median width/length ratio of $0.78(\mathrm{n}=13)$.

The reefs of the lower horizon are slightly smaller (median diameter $=2.2 \mathrm{~m}, 1$ st quartile $=$ $1.5 \mathrm{~m}, 3 \mathrm{rd}$ quartile $=2.6 \mathrm{~m}, \mathrm{n}=11$ ) than the reefs of the upper horizon (median diameter $=2.7 \mathrm{~m}$, 1 st quartile $=2.2 \mathrm{~m}, 3 \mathrm{rd}$ quartile $=3.4 \mathrm{~m}, \mathrm{n}=32$ ). The median nearest neighbor distance of the reefs of the upper horizon is $\sim 6 \mathrm{~m}(\mathrm{n}=38)$ with an aggregation index of $\mathrm{R}=0.638$ (Table 1). Point counts of the lower horizon $(n=4)$ indicate that the reef cores are composed of $48 \%$ of skeletal mudstone/wackestone, $38 \%$ pale and dark mudstone, $8 \%$ sponge skeletons, less than $3 \%$ of vagile skeletal benthos and only $\sim 1 \%$ of calathids. The reef cores of the upper horizon $(n=5)$ differ from the lower horizon in having a higher content of sponge skeletons and no calathids where found ( $25 \%$ of skeletal mudstone/wackestone, $52 \%$ pale and dark mudstone, $21 \%$ sponge skeletons, less than $1 \%$ of vagile skeletal benthos) (Fig. 7F, 7G).

The microfacies of the upper horizon reef cores consists predominantly of a burrowed, silty mudstone to skeletal wackestone that contains abundant trilobite carapaces, echinoderm ossicles, brachiopod shell hash, and sponge spicules. Subordinate patches of clotted microbial micritic mudstone to wackestone occur within and between remains of keratose and lithistid sponge skeletons.

In summary, the bioherms of the Wah Wah Formation are 2-3m wide subcircular to oval patch reefs composed of masses sponge skeletons within silty, burrowed mudstone/wackestone matrix. The compositional heterogeneity among reefs of the Wah Wah Formation is very low, but within reefs, at decimeter scale and below, patches differ in predominance of different types of sponges and matrix components.

Sponge-Rich Reefs of the Table Point Formation, Darriwilian, Newfoundland, Canada

The reef bearing horizon at Pointe Riche is a $\sim 3 \mathrm{~m}$ thick disconformity bounded unit. The limestone above and below the two discontinuity surfaces is a massive burrow mottled skeletal wackestone of more than $5 \mathrm{~m}$ thickness, that contains few distinct flint layers. The reef bearing horizon is more argillaceous than the overlying and underlying beds and consists of thin $(<50 \mathrm{~mm})$ irregular layers of partly slightly, secondarily dolomitized, bioturbated wackestone with a thinning up tendency. The lowermost $0.5 \mathrm{~m}$ of the reef bearing horizon is also rich in argillaceous material, cross bedded, and contains abundant thin meter-sized lenses and channels of skeletal to intraclastic packstone and grainstone and thin layers of dolosiltstone. The predominant grain component is formed by strongly rounded intraclasts and/or peloids, often with a micritic rim. Oncolites are rare. Brachiopods, trilobites, and locally echinoderm ossicles are the dominant skeletal components in the packstone and grainstone. Dendroid bryozoans are a conspicuous but rare component. Halysis and Girvanella are common elements of the microfacies of the intra reef and reef flanking packstone and grainstone. Pulchrilamina was additionally listed by Klappa and James (1980). The reefs form distinctive circular to half-moon shaped patches with a thickness of up to $\sim 1 \mathrm{~m}$, a median diameter of $1.2 \mathrm{~m}(\mathrm{n}=45)$ and a median nearest neighbor distance of $\sim 5 \mathrm{~m}(\mathrm{n}=88)$ (Fig. $4 \mathrm{G})$. The distribution of nearest neighbor distances does not significantly differ from complete spatial randomness (CSR) (see Table 1) and has an aggregation index $\mathrm{R}=0.991$.

Within the reef-bearing horizon, some reefs grew directly on the discontinuity surface, but others nucleated independently of obvious underlying hardgrounds. In contrast to observations of 
Klappa and James 1980, p. 428) we could not detect any preferential substrate for the reef initiation. Echinoderm ossicle rich grainstone and packstone wedges are associated with the reefs and in several places flanking and/or underly the reef cores.

The reef core consists of a grayish-green bioturbated mudstone/wackestone with no clear bedding and with abundant floating stick-like to bowl-shaped lithistid sponges and rare calathids and bryozoans as additional sessile components (Figs. 4G, 11). The sponges are especially abundant at the top $\sim 30 \mathrm{~cm}$ of the reefs, but otherwise no vertical zonation in the reef composition was detected (but see Klappa and James 1980; James and Klappa 1989). The point counts result in a reef composition with a mean of $73 \%$ of reef matrix content, $24 \%$ of sponge skeletons, < $3 \%$ of vagrant benthos skeletons, and less than $0.3 \%$ bryozoans $(\mathrm{n}=10)$ (but compare Klappa and James 1980 which give a 40-70\% of skeletal component in the reefs). The sponge fauna is composed of $37 \%$ Archaeoscyphia, 24\% funnel and cone shaped, and 13\% rod-, sheet-, and globular-shaped specimens (Klappa and James 1980).

The reef core facies at Point Riche consists of patches of skeletal wackestone, clotted micritic mudstone, fenestral mudstone, and patches with filamentous keratose and lithistid sponge fabric (Fig. 11A, 11C). The relative abundance of these patches varies within the reefs and from one reef to another. The microfacies of the reef core of the single reef studied by us at Table Point consists predominantly of a burrowed, slightly secondarily dolomitized mudstone to skeletal wackestone that contains abundant ostracods and sponge spicules. Additionally, patches with filamentous sparitic pattern from keratose sponges, and lithistid sponge skeletons are abundant, and massive sheet-like bryozoans occur.

In summary, the reefs of the Table Point Formation form distinct meter-sized patches, dominated by lithistid and keratose sponge skeletal remains in variable abundance and with an average burrowed mudstone/wackestone matrix content of $73 \%$. The occurrence of Calathium and sheet forming bryozoans is notable. The intra-reef facies consists of burrowed skeletal wackestone with decimeter thick wedges of skeletal-intraclastic packstone/grainstone.

Reefs of the Mingan Formation, Darrwilian, Mingan Islands, Quebec, Canada

Lithistid sponges contribute to reef construction at Île du Fantôme and Île de la Fausse Passe, but sponge-dominated reefs are only found at Île du Fantôme. At both sites, sponges show globular, conical, club-shaped and cup-shaped morphologies. At Île du Fantôme, the intra-Mingan unconformity is well-exposed on the southwestern coastline and forms a paleo-trough, appearing in outcrop at the northern and southern ends of the exposure and dipping below sea level in between. The unconformity has a local paleotopographic relief of around $20 \mathrm{~m}$. More than 40 reefs are exposed on the northern side of this trough, forming a reef belt around $300 \mathrm{~m}$ wide, trending approximately northwest-southeast. Both isolated reefs and reef complexes occur, with a median thickness of $1.1 \mathrm{~m}(\mathrm{n}=16$, range $=0.5-2 \mathrm{~m})$ and a median diameter of $5 \mathrm{~m}(\mathrm{n}=14$, range $=2-18$ $\mathrm{m})$. The median nearest-neighbor distance between reefs is $6.1 \mathrm{~m}(\mathrm{n}=35$, range $=2.6-19.2 \mathrm{~m})$, and reefs are randomly distributed (see Table 1 ) with an aggregation index $\mathrm{R}=0.742$. Reef complexes are more common than isolated reefs, and those with elliptical geometries commonly have long axes aligned in an approximately northeast-southwest direction. Flanking beds interfinger with reef margins, and are composed of grainstone, with fragments of lithistid sponges, echinoderm ossicles, and ramose bryozoans. Maps of the locations of reefs with different dominant reef builders suggest that bryozoan-dominated reefs are more common to the north of the transect, at shallower paleodepths, while sponge-dominated reefs seem more common to the south. The suggestion that this might reflect a weak depth-segregation among reef types in the exposure may be supported by the presence of a deep-water sponge pavement facies at Île de la Fausse Passe.

Most reefs at Île du Fantôme contain both lithistid sponges and encrusting bryozoans, though typically one taxon predominates. Five of the point-counted reefs are dominated by lithistid sponges, which comprise up to $54 \%$ of the reef core $(n=5$, mean $=39 \%$, range $=24-54 \%)$. Reefbuilding sponges are sometimes encrusted by bryozoans, which comprise a relatively minor volumetric component of the sponge-dominated reefs (mean $=11 \%$ ), and which also occur encrusting on reef margins. Ramose and fenestrate bryozoans, the bryozoan Phylloporina, and 
brachiopod and mollusk shells also make minor contributions to reef volume, though typically in reefs which already have a significant encrusting bryozoan component.

In reefs with a significant bryozoan component, bryozoans comprise a mean of $29 \%$ of the reef core volume $(n=4$, range $=17-48 \%)$. Lithistid sponges are typically rarer (mean $6 \%$ of the reef core), though in one case abundant encrusting bryozoans and lithistid sponges occur together. Where bryozoans are abundant, they commonly form a dense, complex, lamellar texture comparable with recent bryoliths (Ernst et al. 2015), but which has diffuse boundaries and incorporates small pockets or layers of the wackestone matrix.

\section{DISCUSSION}

Spatio-Temporal Modes of Reef Growth

Three distinctive temporal modes of reef growth occur within the Lower-Middle Ordovician reefs investigated herein (Fig. 12): mosaic, episodic, and belt and bank modes of reef growth.

Mosaic Mode of Reef Growth.- The reefs of the earliest Ordovician Watts Bight Formation are concentrated in stratigraphic intervals in which they form complexes of stacked layers or banks of coalesced patches with a lateral extent of more than 100 meters but less than $1 \mathrm{~km}$ (see Boyce et al. 2011, fig. 5). Reefal layers of smaller horizontal and vertical extent are abundant below and above these intervals within the Watts Bight Formation (Pratt and James 1986; Knight and James 1987; Knight et al. 2008; Boyce et al. 2011). The reefs commonly grew directly on truncation surfaces (e.g., Figs. 4B, 5) (Knight et al. 2008; Boyce et al. 2011) and form a highly complex spatial mosaic. The partly sponge-rich reefs of the Watts Bight Formation do not differ in general morphology from the sponge-poor or sponge-lacking thrombolite patches, coalesced banks or sheet-forming thrombolite reefs of the Watts Bight Formation elsewhere (Figs. 4A, 4B, 5) and of the overlying Boat Harbor and Catoche formations (compare Pratt et al. 1982; Pratt and James 1989a, 1989b; Knight et al. 2007, 2008; Pruss and Knoll 2017).

A general model for the depositional setting of the reef formation in these lithological units has been suggested by Pratt and James (1986) for the lower Ordovician and by (Cowan and James 1993, 1996) for the upper Cambrian part of the carbonate platform of western Newfoundland. Thrombolitic reefs formed locally predominantly on synsedimentarily lithified tops or on truncation surfaces of meter-scale mixed siliciclastic-carbonate shallowing-up cycles (Cowan and James 1993, 1996). These cycles are interpreted as resulting from spatially highly dynamic and complex conditions of carbonate formation, transport and lithification, which formed a subtidal to peritidal seascape of shoals and troughs on a large tropical shelf (Cowan and James 1993, 1996). Third order sea level fluctuations and change in subsidence rates are considered to be a relevant controlling factor only at a high level platform scale and on the thickness-scale of tens to hundreds of meters. The meter scale cyclicity and small-scale seascape mosaic is interpreted largely as authigenic and self-organized (Cowan and James 1996). Within the lower Ordovician strata the high level cyclicity is less well developed than in the Cambrian strata, but the small scale facies mosaic with local shoals, coalescent reef patches, reef complexes and troughs is very similar to that of the upper Cambrian (Pratt and James 1986; Knight and James 1987; Knight et al. 2008). Thrombolitic reefs are interpreted to have preferentially developed on the windward sides of local shoals on areas with early lithification of the sea bottom and/or truncation surfaces (Pratt and James 1986). Notably, the above described small scale facies pattern occurs across a very large area covering a distance of several hundred kilometers along Western Newfoundland (e.g., Knight et al. 2008). Such a mosaic mode of reef growth is not restricted to Newfoundland but occurs across large areas of the eastern and southern Laurentia paleocontinent (e.g., New York, USA, Landing 2012; Northeast Greenland, McCobb et al. 2014; Svalbard, Kröger et al. 2017b; west Texas, Toomey and Nitecki 1979, fig. 21). Episodic Mode of Reef Growth.- The reefs within the Fillmore and Wah Wah formations (Tremadocian-Floian) and within the Table Point Formation (Darriwilian) occur in distinctive, well defined intervals of $<5 \mathrm{~m}$ thickness within much thicker lithological units $(550 \mathrm{~m}, 79 \mathrm{~m}$, more than $100 \mathrm{~m}$, respectively). Reef occurrences are limited to these distinctive layers. The reefal horizons are bounded by depositional unconformities at their base and top. 
Little is known about the lateral extent and isochronous or diachronous character of the episodic reef occurrences. The occurrences appear to be quasi isochronous at a lateral scale of tens of kilometers within the limits of stratigraphical resolution, and hence have an event character at this spatiotemporal scale (Church 1974; Klappa and James 1980). Further away from the Fillmore and Wah Wah formations of the Ibex area roughly time equivalent sponge and Calathium rich reef horizons occur within the Shingle Limestone, Nevada, (Johns 1994, fig. 4) and within the Garden City Formation, northern Utah (Ross 1977; Morgan 1988; Pearce 2012). These occurrences testify that reefs developed in distinctive intervals during the latest Floian age over a vast area of today's western USA, but a high resolution correlation of these intervals is not available at this time.

Terrigenous input into the depositional system, which is high in the western USA, cannot be the sole controlling factor for the episodic character of the reef growth because it is negligible in the Table Point Formation. Exposed lateral or vertical transitions from a mosaic to an episodic mode of reef growth can give additional evidence for controlling factors. Such a transition is not known from sponge or Calathium rich reefs investigated herein. But in western Newfoundland four distinct meter-thick horizons with skeleton-poor thrombolite reefs occur within the lower Catoche Formation (Didymograptus bifidus graptolite Zone, late Floian) (Zhang and Barnes 2004; Fig. 13), which can be traced from the Port au Choix Peninsula $\sim 7 \mathrm{~km}$ toward the east to Bustard Cove (Knight and James 1987). These episodic reef occurrences are informative, because in the same stratigraphic interval within the middle Catoche Formation complex dispersed accumulations of thrombolites that grew in the mosaic mode, are known from the Port au Port Peninsula $\sim 260 \mathrm{~km}$ toward the south (Knight et al. 2007). These southernmost occurrences are interpreted to represent more distal depositional environments at the rim of the extensive western Newfoundland carbonate platform (Knight and James 1987). This means that the reefal episodes of the Catoche Formation at Port au Choix represent short intervals of extension of the reef growth into the inner platform from more distal areas with more continuous reef growth $\sim 260 \mathrm{~km}$ toward the south. However, the reefal episodes at Port au Choix cannot be interpreted as resulting from backward stepping during transgression, because the middle member of the Catoche Formation was deposited under comparable low sea level (compared with the lower and upper members; Zhang and Barnes 2003). In this context it is important to note that episodic reefs grew preferably directly on or above major erosional surfaces (Fig. 13). The reefs grew directly after major (fourth level) lowstand events when sea level rose within a generally low sea level regime.

Hard substrate preference of reef growth is a general feature in the lower Ordovician carbonate platform of Western Newfoundland (Pratt and James 1986; Cowan and James 1993, 1996). Hard substrates are prevalent on the more exposed distal rim of the platform where they probably facilitated the mosaic mode growth pattern (e.g., Pratt and James 1986). The episodic growth of reefs on the inner platform then can be best explained as resulting from a combination of widespread availability of hard substrate, reduced siliciclastic input, and available accommodation space during sea level rise after major regressions. This model is consistent with the unconformity bounded episodic reef occurrences within the Fillmore, Wah Wah, and Table Head formations. The predominant sediment in the former two formations is marl to siltstone (Fig. 8; Hintze 1973), and in the latter a burrow-mottled nodular lime mudstone (e.g., Klappa and James 1980), which can be best interpreted as originally forming a shallowly burrowed soft substrate (see also Droser and Bottjer 1989; Tarhan 2018, fig. 15). Hard substrate probably was restricted within these formations to the truncated surfaces of parasequences and local patches of intraformational (mostly flat pebble) conglomerates. Episodic reef growth was possible on these hard substrates only during times of rapid transgression, when enough accommodation space was available.

Belt-and-Bank Mode of Reef Growth.- The reefs of the Mingan Formation (Darriwilian) are distributed as vertically dispersed patches, spatially concentrated along belt-like zones with widths of few hundred meters and an unknown larger lateral expansion (Penny et al. 2020). The exposed and preserved thickness of the reefal carbonates in the belts does not exceed $15 \mathrm{~m}$ (Penny et al. 2020). The belt mode of reef growth differs from the mosaic mode of reef growth in two aspects. The first aspect is the spacing of the reefs, which is not or rarely coalescent and forms distinct 
vertically and laterally relatively dispersed patches (Fig. 14). The second aspect is the relation of the truncation surfaces to the reef growth. In the mosaic mode of reef growth reefs predominantly grew directly on the hard substrate of local truncation surfaces or are directly stacked on each other (Fig. 5). The reefs of the belt mode commonly grew above or below local truncation surfaces and the growth in between truncation surfaces started on larger metazoan (coral, bryozoan, sponge) skeletons within the predominantly skeletal grainstone-packstone lithology of the interreef facies (Kröger et al. 2017a; Penny et al. 2020).

The metazoan reefs of the Chazy Group (Darriwilian) of the Lake Champlain area (upstate New York, USA and southern Quebec, Canada) are similar to the Mingan reefs with respect to the reefs of the Mingan Formation in being patch reefs with low to medium grade of aggregation (visual observation based on own field observation by BK, see also Oxley and Kay 1959, fig. 7; Pitcher 1964, figs. 15, 19, 27; Kapp 1975). The Chazy reefs are also similar to the Mingan reefs with respect to reef growth, which was commonly initiated on skeletons of larger metazoans (mostly corals) (Pitcher 1964) and not dependent on underlying truncation surfaces (Kröger et al. 2017a). The Chazy reefs are interpreted as reef banks, which developed on submerged tectonical highs surrounded by non-reefal deeper settings (Oxley 1951; Oxley and Kay 1959). This is evidenced by lateral thickness differences between reefal and non reefal areas in the Chazy Group (Oxley 1951).

This reef growth in distinct belts and banks of hundreds of meters in dimension in which reefs grew vertically and laterally as dispersed patches largely independent (at meter scale) from truncation surfaces is different from the mosaic mode, where reefs grew over vast areas largely constrained to the hard substrate of local truncation surfaces. The growth of individual reefs within the Mingan Formation and within the Chazy Group was regularly terminated at local parasequence boundaries, similar to reefs of the Watts Bight Formation. Frequently, reef growth then reinitiated on top of the resulting meter-scale topography on existing truncation and/or karst surfaces, in overlying parasequences. However, in contrast to the older settings (e.g., the Watts Bight Formation), reef growth was also often initiated on patches without direct or obvious association to a local hard substrate. This resulted in deposits with distinct regional concentrations of vertically and horizontally dispersed individual patch reefs. These are radically different from deposits in episodic growth mode, where reef growth is usually limited to a single bed, and from the mosaic growth mode, where widespread growth is largely limited to local truncation surfaces.

Paleoecological aspects of spatio-temporal modes of reef growth

Geometries of carbonate and mixed siliciclastic-carbonate depositional systems are principally controlled by an interplay of subsidence, sea level, siliciclastic input, and carbonate production (Kendall and Schlager 1981; Walker et al. 1983; Burchette and Wright 1992). Because carbonate production in Phanerozoic depositional systems is primarily a biological process, the evolving carbonate producing biota, their community structure, and their specific modes of life are an essential factor for their spatial accumulation pattern (e.g., Pomar and Kendall 2008; Pomar and Haq 2016). Spatial distributions of modern reefs, and more generally, facies mosaics of modern shallow water seascapes often show a power-law frequency distribution (e.g., Drummond and Dugan 1999; Purkis and Kohler 2008); a pattern that has been interpreted as resulting from a complex interplay of reef growth with inherited antecedent (Pleistocene) karstic topographies (Purkis and Kohler 2008; Schlager and Purkis 2015). However, relatively few quantitative spatial lithofacies analyses compare reef patch sizes and patch distances (e.g., Rankey and Garza-Pérez 2012), and it remains an open question whether highly clustered reef pattern and power-law lithofacies frequency distributions are a general characteristic of modern reef seascapes. The frequency distributions of nearest neighbor distances and patch sizes of Ordovician reefs, analyzed herein, are highly variable (Figs. 15, 16). And the size distribution of reefs from the Wah Wah Formation is consistent with a model of normal frequency distribution (Shapiro-Wilk normality test, $\mathrm{p}=0.461$ ). Hence, power-law distributions are not ubiquitous in Ordovician strata. Also, based on our limited data, the spatial distribution of reefs of the belt and bank mode of reef growth appears to 
be less clustered (mean $\mathrm{R}=0.74, \mathrm{n}=2$ ) than that of the episodic mode of reef growth (mean $\mathrm{R}=$ $0.46, \mathrm{n}=4)$.

Lithofacies patch size, patch distribution, and temporal patch persistence are not independent from ecological community structure in modern reefs and seascapes (e.g., Parravicini et al. 2013; Zarnetske et al. 2017; Sampayo et al. 2020). Therefore, we assume that the different spatio-temporal modes of reef growth, described herein, represent different ecological paleocommunities and potentially reflect hitherto unrecognized macroevolutionary trends.

The Lower-Middle Ordovician is an interval of marked changes in global reef composition. The increasing role of metazoan versus microbial reef builders and the varying dominance among the skeletal metazoans are the main aspects of these changes. The focus of our analysis was on the sponge and Calathium rich reefs of this interval. We did not account for variations in relative abundance of microbial versus metazoan dominated reefs, and our analysis did not distinguish between sponge taxa. Any potential trends at these observational levels therefore remain undetected. We found high variability in skeletal content, and compositional heterogeneity within and among the reefs, but no overarching trend.

However, the reefs of the Watts Bight Formation, which are the oldest in this study, differ from all other reefs we investigated in containing very high percentages $(>>50 \%)$ of microbial nonskeletal carbonates (Fig. 6C). The macrofabric of these reefs is dominated by a regular saccatemaceriate pattern, very similar to that described in Shapiro and Awramik (2006) and Lee et al. (2010), and is interpreted by the former as a time specific thrombolitic microbialite with a late Cambrian-Early Ordovician range. The younger sponge rich reefs all contain much lower percentages of regular microbial textures and at the same time their micrite-rich non-skeletal matrix is generally heavily burrowed (Figs. 7, 11). The increase in burrowing intensity within unconsolidated Ordovician reef sediments has never been quantified and we cannot provide additional data. However, the shift from regular microbial reef textures, toward irregularly burrowed reef textures, is consistent with generally increasing burrowing intensities observed in Ordovician marine strata (Droser and Bottjer 1989; Tarhan et al. 2015; Buatois et al. 2016).

In Western Newfoundland the most outstanding higher order trend in reef growth pattern is the gradual disappearance of the mosaic mode of reef growth across the carbonate platform. Reefs which are developed in mosaic mode occur as dispersed patches or tabular meter-thick sheets of thrombolites, with and without skeletal metazoans, and often with regular microbial textures. These reefs are an important component of the late Cambrian and Lower Ordovician carbonates of Newfoundland, such as in the Watts Bight Formation (e.g., Pratt and James 1986; Cowan and James 1993, 1996). Concentrations of reefs occur at the outer platform, where they form complex agglomerations that are interpreted as parts of the platform rim (e.g., Knight and James 1987). The mosaic mode of reef distribution gradually becomes less widespread toward the late Floian age, especially within carbonates of the inner platform (Knight and James 1987); it is unknown from Middle Ordovician sediments of the region. This disappearance of the mosaic mode of reef growth is probably not restricted to Western Newfoundland, but applies generally to the vast carbonate platform that extended over large areas of the eastern Laurentia paleocontinent (see above).

This trend is not mirrored on the western side of the Laurentian paleocontinent, where a mixed siliciclastic-carbonate sedimentation prevailed. Tremadocian and Floian reefs occur predominantly in an episodic mode of growth across the inner platform sediments of Nevada and Utah, USA (Hintze 1953, 1974; Ross 1977; and see above). However, to our knowledge, the mosaic mode of reef growth does not exist in post-Floian sediments in this region. Therefore, we assume that the mosaic mode of reef growth was specific to shallow late Cambrian-Lower Ordovician tropical carbonate platforms dominated by thrombolitic reefs (with and without skeletal metazoans) and its main controlling factor was the availability of hard substrate and accommodation space.

In contrast, to our knowledge, reef growth in the bank and belt mode exists in Ordovician deposits only in strata of Darriwilian age or younger (see above). These reefs contain abundant skeletal metazoans as framework builders and individual reef growth is less strictly associated with truncation surfaces and hardgrounds, and instead individual reefs may also have initiated on 
fragments of larger skeletal debris within soft substrate environments (Kröger et al. 2017a). Reef belts and banks are spatially heterogenous, and represent topographically highly differentiated original seascapes at scales of hundreds of meters (Penny et al. 2020).

A trend from a dominance of the mosaic mode with a relatively low taxonomic richness toward belt and bank mode of reef growth with highly diverse seascapes in tropical carbonate depositional systems during the Middle Ordovician is a scenario that is likely, based on the data presented herein. However, future studies should also consider other paleogeographic regions with extensive Ordovician reef development, such as China and Siberia.

\section{CONCLUSIONS}

Sponge-rich reefs form a common component within the spectrum of reefal deposits of the EarlyMiddle Ordovician interval. A comparison of spatial occurrences of sponge-rich reefs from eight sites from shallow marine depositional settings across the Laurentia paleocontinent allows us to distinguish three seascape level reef growth patterns. In the mosaic mode of reef growth, coalescent and sheet-like reefs grew directly on truncation surfaces and form a highly complex spatial mosaic. In the episodic mode reefs grew in distinct, often unconformity bounded horizons within lithological units that have a much larger thickness. And in the belt-and-bank mode reefs and reef complexes grew vertically and laterally as dispersed patches largely independent from truncation surfaces and form belts and banks of hundreds of meters in dimension.

The oldest reefs studied herein were deposited during the earliest Tremadocian epoch and are part of a reef succession representative of the mosaic mode of reef growth. These oldest reefs contain a considerable amount of carbonate with microbial textures, such as mesoclots and Renalcis, which commonly form a regular saccate-maceriate macrofabric.

In younger reefs studied herein, regular microbial textures are less common and instead the non-skeletal matrix is more abundantly heavily bioturbated. In reefs of Darriwilian age and younger the belt and bank mode of reef growth occurs, and these youngest reefs contain abundant skeletal metazoan frame builders. Reefs of the belt and bank mode have the highest aggregation index and accordingly their spacing is most dispersed. The aggregation index is a useful tool to quantify reef spacing at seascape level, but more data are needed to reach statistically robust results for comparison of different modes of reef growth.

The comparatively weak association of reefs of the belt and bank mode with truncation surfaces and hardgrounds, and the high abundance of diverse reef building metazoan skeletons in these reefs, suggest that specific reef forming paleocommunities led to this distinct seascape scale reef growth pattern. A general shift in dominance from mosaic mode toward bank and belt mode of reef growth during the Ordovician as a consequence of changing reefal paleocommunities is therefore a likely scenario. However, comparisons with Ordovician reef occurrences from other regions of the world are needed to further support or reject this hypothesis.

\section{ACKNOWLEDGMENTS}

We thank the staff of Parks Canada for processing our application to work in the Mingan Archipelago National Park Reserve, the Gros Morne National Park Reserve, and at Port au Choix National Historic Site, and are grateful to Danielle Shaienks (Havre-St-Pierre, Quebec, Canada), Jeri Graham (Rocky Harbour, Newfoundland, Canada) for field assistance, and Pierre St-Hilaire (Havre-St-Pierre, Quebec, Canada) for transport to field localities. We thank the staff of Bureau of Land Management, Utah State Office, especially Allison Ginn and Greg McDonald (Salt Lake City, Utah, USA) for processing our application and supporting our work in Millard County, Utah, USA. We are grateful for useful suggestions for fieldwork and outcrop localities to Forest Gahn (Rexburg, Idaho), Noel James (St. Johns, Newfoundland, Canada), Paul Jamison (Logan, Utah, USA), Rachel Wood (Edinburgh, UK), Richard Hofmann (Berlin, Germany), Seth Finnegan (Berkeley, California, USA), and Svend Stouge (Copenhagen, Denmark). We are also grateful to Michael Mechenich (Helsinki, Finland) for early discussions about the analysis of spatial data in R. We thank our reviewers Emily Mitchell and Sara Pruss who provided very valuable comments and constructive criticism to an earlier version of the manuscript. This work is part of the project Ecological engineering as a biodiversity driver in deep time, funded by the Academy of Finland. This paper is 
a contribution to the IGCP program 653 "The Onset of the Great Ordovician Biodiversification Event".

REFERENCES

ADACHI, N., EZAKI, Y., LIU, J., AND Cao, J., 2009, Early Ordovician reef construction in Anhui Province, South China: a geobiological transition from microbial-to metazoan-dominant reefs: Sedimentary Geology, v. 220, p. 1-11.

AlBERSTAD, L.P. AND REPETSKI, J.E., 1989, A Lower Ordovician sponge/algal facies in the southern United States and its counterparts elsewhere in North America: PALAIOS, v. 4, p. $225-242$.

BADDELEY, A.J. and TURNER, R., 2005, Spatstat: An R package for analyzing spatial point patterns: Journal of Statistical Software, v. 12, p. 1-42.

Bolton, T.E. AND CUFFEY, R.J., 2005, Bryozoa of the Romaine and Mingan formations (Lower and Middle Ordovician) of the Mingan Islands, Quebec, Canada: Bryozoan Studies 2004: Proceedings of the 13th International Bryozoology Association Conference, Concepcion/Chile, 11-16 January 2004, Taylor and Francis, p. 25-42.

BonetT, D.G., 2006, Confidence interval for a coefficient of quartile variation: Computational Statistics and Data Analysis, v. 50, p. 2953-2957.

Boyce, W.D., McCoBB, L.M.E., AND KNIGHT, I., 2011, Stratigraphic studies of the Watts Bight Formation (St. George Group), Port au Port Peninsula, western Newfoundland: Current Research: Government of Newfoundland and Labrador, Department of Natural Resources, Mines Branch, Report, v. 11, p. 215-240.

BRUNTON, F.R. AND DIXON, O.A., 1994, Siliceous sponge-microbe biotic associations and their recurrence through the Phanerozoic as reef mound constructors: PALAIOS, v. 9, p. 370-387.

Buatois L.A., Mangano, M.G., Olea, R.A., And Wilson, M.A., 2016, Decoupled evolution of soft and hard substrate communities during the Cambrian Explosion and Great Ordovician Biodiversification Event: Proceedings of the National Academy of Sciences, v. 113, p. 69456948.

BuRChetTe, T.P. AND WRIGHT, V.P., 1992, Carbonate ramp depositional systems: Sedimentary Geology, v. 79, p. 3-57.

CANAS, F. AND CARRERA, M., 1993, Early Ordovician microbial-sponge-receptaculitid bioherms of the Precordillera, western Argentina: Facies, v. 29, p. 169-178.

CHURCH, S.B., 1974, Lower Ordovician patch reefs in western Utah: Brigham Young University Geology Studies, v. 21, p. 41-62.

CHURCH, S.B., 1991, A new Lower Ordovician species of Calathium, and skeletal structure of western Utah calathids: Journal of Paleontology, v. 65, p. 602-610.

Clark, P.J. AND EVANS, F.C., 1954, Distance to nearest neighbor as a measure of spatial relationships in populations: Ecology, v. 35, p. 445-453.

COWAN, C.A. AND JAMES, N.P., 1993, The interactions of sea-level change, terrigenous-sediment influx, and carbonate productivity as controls on upper Cambrian Grand Cycles of western Newfoundland, Canada: Geological Society of America Bulletin, v. 105, p. 1576-1590.

COWAN, C.A. AND JAMES, N.P., 1996, Autogenic dynamics in carbonate sedimentation; meterscale, shallowing-upward cycles, upper Cambrian, western Newfoundland, Canada: American Journal of Science, v. 296, p. 1175-1207.

CUFFEY, R.J., 2006, Bryozoan-built reef mounds: the overview from integrating recent studies with previous investigations: Courier Forschungsinstitut Senckenberg, v. 257, p. 35-47.

DESROCHERS, A. AND JAMES, N.P., 1988, Early Paleozoic surface and subsurface paleokarst: Middle Ordovician carbonates, Mingan Islands, Quebec, in N.P. James and P.W. Choquette (eds.), Paleokarst: Springer, New York, p. 183-210.

Desrochers, A. AND JAMES, N.P., 1989, Middle Ordovician (Chazyan) bioherms and biostromes of the Mingan Islands, Quebec: Canadian Society of Petroleum Geologists Memoir 13, v. Reefs, Canada and adjacent areas, p. 183-191. 
Droser, M.L. AND BotTJER, D.J., 1989, Ordovician increase in extent and depth of bioturbation: implications for understanding early Paleozoic ecospace utilization: Geology, v. 17, p. 850 852.

DRUMMOND, C.N. AND DUGAN, P.J., 1999, Self-organizing models of shallow-water carbonate accumulation: Journal of Sedimentary Research, v. 69, p. 939-946.

ERnst, A., MunNECKE, A., AND OSWALD, I., 2015, Exceptional bryozoan assemblage of a microbial-dominated reef from the early Wenlock of Gotland, Sweden: GFF, v. 137, p. 102125.

Evans, K.R., MiLler, J.F., AND DAtTilo, B.F., 2003, Sequence stratigraphy of the Sauk Sequence: 40th anniversary field trip in western Utah, in T.W. Swanson (ed.), Western Cordillera and adjacent areas, Field Guide 4: The Geological Society of America, Boulder, p. 17-37.

HINTZE, L.F., 1951, Ordovician Stratigraphy of Central Utah: Geology of the Canyon, House and Confusion Ranges, Millard County, Utah: Guidebook to the Geology of Utah: Intermountain Association of Petroleum Geologists, Distributed by Utah Geological and Mineralogical Survey, Salt Lake City, Utah, v. 6, p. 38-43.

HINTZE, L.F., 1953, Lower Ordovician trilobites from western Utah and eastern Nevada: Utah Geological and Mineralogical Survey Bulletin 48, 249 p.

HINTZE, L.F., 1973, Lower and Middle Ordovician stratigraphic sections in the Ibex area, Millard County, Utah: Brigham Young University Geology Studies, v. 20, p. 3-36.

HonG, J., CHOH, S.-J., AND LEE, D.-J., 2015, Untangling intricate microbial-sponge frameworks: the contributions of sponges to Early Ordovician reefs: Sedimentary Geology, v. 318, p. 7584.

Hui, C., VeldtMAn, R., AND McGeOCh, M.A., 2010, Measures, perceptions and scaling patterns of aggregated species distributions: Ecography, v. 33, p. 95-102.

JAMES, N.P. AND KLAPPA, C.F., 1989, Lithistid sponge bioherms, early Middle Ordovician, western Newfoundland: Canadian Society of Petroleum Geologists Memoir 13, v. Reefs, Canada and adjacent areas, p. 196-200.

Ji, Z. AND BARNES, C.R., 1994, Conodont paleoecology of the Lower Ordovician St. George Group, Port au Port Peninsula, western Newfoundland: Journal of Paleontology, v. 68, p. 1368-1383.

JoHns, R.A., 1994, Ordovician lithistid sponges of the Great Basin: Nevada Bureau of Mines and Geology Open File Report, v. 94, p. 1-156.

KAPP, U.S., 1975, Paleoecology of Middle Ordovician stromatoporoid mounds in Vermont: Lethaia, v. 8, p. 195-207.

Kendall, C.G.S. AND SCHLAGER, W., 1981, Carbonates and relative changes in sea level: Marine Geology, v. 44, p. 181-212.

KLAPPA, C.F. AND JAMES, N.P., 1980, Small lithistid sponge bioherms, early middle Ordovician table head group, western Newfoundland: Bulletin of Canadian Petroleum Geology, v. 28, p. 425-451.

KlaPPA, C.F., Opalinski, P.R., AND JAMES, N.P., 1980, Middle Ordovician Table Head group of western Newfoundland: a revised stratigraphy: Canadian Journal of Earth Sciences, v. 17, p. $1007-1019$.

Knight, I., AZMY, K., Boyce, W.D., AND LAvoIE, D., 2008, Tremadocian carbonate rocks of the lower St. George Group, Port au Port Peninsula, western Newfoundland: lithostratigraphic setting of diagenetic, isotopic and geochemistry studies: Current Research: Newfoundland and Labrador Department Mines and Energy, Geological Survey Report, v. 8, p. 115-149.

KNight, I., AZMY, K., GREENE, M., AND LAVoIE, D., 2007, Lithostratigraphic setting of diagenetic, isotopic, and geochemistry studies of Ibexian and Whiterockian carbonates of the St. George and Table Head groups in western Newfoundland: Current Research: Newfoundland and Labrador Department of Natural Resources Geological Survey Report, v. 7, p. 55-84.

KNIGHT, I. AND JAMES, N.P., 1987, The stratigraphy of the Lower Ordovician St. George Group, western Newfoundland: the interaction between eustasy and tectonics: Canadian Journal of Earth Sciences, v. 24, p. 1927-1951. 
KröGER, B., Desrochers, A., AND ERnst, A., 2017a, The Reengineering of reef habitats during the Great Ordovician Biodiversification Event: PALAIOS, v. 32, p. 584-599.

Kröger, B., Finnegan, S., Franeck, F., AND Hopkins, M., 2017b, The Ordovician succession adjacent to Hinlopenstretet, Ny Friesland, Spitsbergen: American Museum Novitates, v. 3882, p. 1-28.

LANDING, E., 2012, The great American carbonate bank in eastern Laurentia: Its births, deaths, and linkage to paleooceanic oxygenation (early Cambrian-Late Ordovician, in J.R. Derby, R.D. Fritz, S.A. Longacre, W.A. Morgan, and C.A. Sternbach (eds.), The Great American Carbonate Bank: The Geology and Economic Resources of the Cambrian-Ordovician Sauk Megasequence of Laurentia: American Association of Petroleum Geologists, Tulsa, Oklahoma, p. 451-492

Lavoie, D., Desrochers, A., Dix, G.E.R., Knight, I., AND Salad Hersi, O., 2012, The great American carbonate bank in Eastern Canada: an overview, in J.R. Derby, R.D. Fritz, S.A. Longacre, W.A. Morgan, and C.A. Sternbach (eds.), The Great American Carbonate Bank: The Geology and Economic Resources of the Cambrian-Ordovician Sauk Megasequence of Laurentia: American Association of Petroleum Geologists, Tulsa, Oklahoma, p. 499-523.

LEe, J.-H., ChEN, J., AND CHOUGH, S.K., 2010, Paleoenvironmental implications of an extensive maceriate microbialite bed in the Furongian Chaomidian Formation, Shandong Province, China: Palaeogeography, Palaeoclimatology, Palaeoecology, v. 297, p. 621-632.

LeE, J.-H., Dattilo, B.F., MrozeK, S., Miller, J.F., AND Riding, R., 2019, Lithistid spongemicrobial reefs, Nevada, USA: filling the late Cambrian 'reef gap': Palaeogeography, Palaeoclimatology, Palaeoecology, v. 520, p. 251-262.

LEE, J.-H. AND RIDING, R., 2018, Marine oxygenation, lithistid sponges, and the early history of Paleozoic skeletal reefs: Earth-Science Reviews, v. 181, p. 98-121.

LEE, M., Sun, N., CHOH, S.-J., AND LEE, D.-J., 2014, A new Middle Ordovician reef assemblage from north-central China and its palaeobiogeographical implications: Sedimentary Geology, v. 310, p. 30-40.

Lindskog, A., Costa, M.M., RAsmussen, C.M.Ø., Connelly, J.N., AND ERIKSSON, M.E., 2017, Refined Ordovician timescale reveals no link between asteroid breakup and biodiversification: Nature Communications, v. 8, p. 14066.

McCobB, L.M.E., BoyCE, W.D., KNIGHT, I., AND Stouge, S., 2014, Early Ordovician (Skullrockian) trilobites of the Antiklinalbugt Formation, northeast Greenland, and their biostratigraphic significance: Journal of Paleontology, v. 88, p. 982-1018.

Morgan, S.K., 1988, Petrology of Passive Margin-Epeiric Sea Sediments: The Garden City: Unpublished M.S. thesis, Department of Geology, Utah State University, Logan, Utah, 168 p.

Normore, L.S., Zhen, Y.Y., Dent, L.M., Crowley, J.L., P.I.G., AND Wingate, M.T.D., 2018, Early Ordovician CA-IDTIMS U-Pb zircon dating and conodont biostratigraphy, Canning Basin, Western Australia: Australian Journal of Earth Sciences, v. 65, p. 61-73.

OXLEY, P., 1951, Chazyan reef facies relationships in the northern Champlain Valley: Bulletin of the Denison University Journal Scientific Laboratory, v. 42, p. 92-111.

OXLEY, P. AND KAY, G.M., 1959, Ordovician Chazyan series of Champlain Valley, New York and Vermont, and its reefs: AAPG Bulletin, v. 43, p. 817-853.

Parravicini, V., Kulbicki, M., Bellwood, D.R., Friedlander, A.M., Arias-GonZalez, J.E., Chabanet, P., Floeter, S.R., Myers, R., Vigliola, L., D’Agata, S., AND Mouillot, D., 2013, Global patterns and predictors of tropical reef fish species richness: Ecography, v. 36, p. $1254-1262$.

PEARCE, H., 2012, A study of the bioherms of the Early Ordovician Garden City Formation and a literature review of Early Ordovician Organic Buildups: Utah State University, All Graduate Plan B and other Reports, v. 193, p. 1-78.

PenNy, A.M., Desrochers, A., AND KRÖGER, B., 2020, Metazoan reef construction in a Middle Ordovician seascape: a case study from the Mingan Island, Quebec: PALAIOS, v. 35, p. 327341. 
PITCHER, M., 1964, Evolution of Chazyan (Ordovician) reefs of eastern United States and Canada: Bulletin of Canadian Petroleum Geology, v. 12, p. 632-691.

Pittman, S., Kneib, R., Simenstad, C., AND NagelKerken I., 2011, Seascape ecology: application of landscape ecology to the marine environment: Marine Ecology Progress Series, v. 427 , p. $187-302$.

PLOTNICK, R.E., 2017, Recurrent hierarchical patterns and the fractal distribution of fossil localities: Geology, v. 45, p. 295-298.

POMAR, L. AND HAQ, B.U., 2016, Decoding depositional sequences in carbonate systems: concepts vs experience: Global and Planetary Change, v. 146, p. 190-225.

POMAR, L. AND KENDALL, C.G.S., 2008, Architecture of carbonate platforms: a response to hydrodynamics and evolving ecology, in J. Lukasik, and J.A. Simo (eds.), Controls on Carbonate Platform and Reef Development, Society of Economic Paleontologists and Mineralogists (Society for Sedimentary Geology) Special Publication 89, p. 187-216.

PRATT, B.R. AND JAMES, N.P., 1982, Cryptalgal-metazoan bioherms of early Ordovician age in the St. George Group, western Newfoundland: Sedimentology, v. 29, p. 543-569.

Pratt, B.R. AND JAMES, N. P., 1986, The St. George Group (Lower Ordovician) of western Newfoundland: tidal flat island model for carbonate sedimentation in shallow epeiric seas: Sedimentology, v. 33, p. 313-343.

PRATT, B.R. AND JAMES, N.P., 1989a, Coral-Renalcis-thrombolite reef complex of Early Ordovician age, St. George Group, western Newfoundland: Canadian Society of Petroleum Geologists Memoir 13, v. Reefs, Canada and adjacent areas, p. 224-230.

PRATT, B.R., AND JAMES, N.P., 1989b, Early Ordovician thrombolite reefs, St. George Group, Western Newfoundland: Canadian Society of Petroleum Geologists Memoir 13, v. Reefs, Canada and adjacent areas, p. 231-240.

PRUSS, S.B. AND KNOLL, A.H., 2017, Environmental covariation of metazoans and microbialites in the Lower Ordovician Boat Harbour Formation, Newfoundland: Palaeogeography, Palaeoclimatology, Palaeoecology, v. 485, p. 917-929.

PURKIS, S.J. AND KOHLER, K.E., 2008, The role of topography in promoting fractal patchiness in a carbonate shelf landscape: Coral Reefs, v. 27, p. 977-989.

Purkis, S., Kohler, K., Riegl, B., And Rohmann, S., 2007, The statistics of natural shapes in modern coral reef landscapes: The Journal of Geology, v. 115, p. 493-508.

R CORE TEAM (2017). R: A language and environment for statistical computing. R Foundation Statistical Computing, Vienna, Austria. URL: https://www.R-project.org/

RANKEY, E.C. AND GARZA-PÉREZ, J.R., 2012, Seascape metrics of shelf-margin reefs and reef sand aprons of Holocene carbonate platforms: Journal of Sedimentary Research, v. 82, p. 53-71.

RigbY, J.K. AND DESROCHERS, A., 1995, Lower and Middle Ordovician Lithistid Demosponges from the Mingan Islands, Gulf of St. Lawrence, Quebec, Canada: Journal of Paleontology, v. 69, Supplement S41, p. 1-35.

Ross, JR., R.J., 1977, Ordovician Paleogeography of the Western United States, in A.E. Fritsche, C.H. Stevens, and J.H. Stewart (eds.), Paleozoic Paleogeography of the Western United States: Pacific Coast Paleogeography Symposium I, April 22, 1977, Bakersfield, California: Pacific Section, Society of Economic Paleontologists and Mineralogists (Society for Sedimentary Geology), Los Angeles, California, p. 19-38.

Ross, JR,, R.J., Hintze, L.F., Ethington, R.L., Miller, J.F., TAYloR, M.E., AND RePETSKi, J.E., 1997, The Ibexian, lowermost series in the North American Ordovician: U.S. Geological Survey Professional Paper 1579-A, p. 1-49.

Ross, JR., R.J. AND JAMES, N.P., 1987, Brachiopod biostratigraphy of the middle Ordovician Cow Head and Table Head groups, western Newfoundland: Canadian Journal of Earth Sciences, v. 24, p. 70-95.

SAMPAyo, E.M., RofF, G., Sims, C.A., RAChEllo-Dolmen, P.G., AND PANDOlFi, J.M., 2020, Patch size drives settlement success and spatial distribution of coral larvae under space limitation: Coral Reefs, v. 39, p. 387-396. 
SHAPIRO, R.S. AND AWRAMIK, S.M., 2006, Favosamaceria cooperi new group and form: a widely dispersed, time-restricted thrombolite: Journal of Paleontology, v. 80, p. 411-422.

SHEN, Y. AND NeUWEILER, F., 2018, Questioning the microbial origin of automicrite in Ordovician calathid-demosponge carbonate mounds: Sedimentology, v. 65, p. 303-333.

SCHLAGER, W. AND PURKIS, S., 2015, Reticulate reef patterns - antecedent karst versus selforganization: Sedimentology, v. 62, p. 501-515.

STENZEL, S.R., KNIGHT, I., and JAMES, N.P., 1990, Carbonate platform to foreland basin: revised stratigraphy of the Table Head Group (Middle Ordovician), western Newfoundland: Canadian Journal of Earth Sciences, v. 27, p. 14-26.

Stouge, S.S., 1984, Conodonts of the Middle Ordovician Table Head Formation, western Newfoundland: Fossil and Strata, v. 16, p. 1-145.

TARHAN, L.G., 2018, The early Paleozoic development of bioturbation-evolutionary and geobiological consequences: Earth-Science Reviews, v. 178, p. 177-207.

Tarhan, L.G., Droser, M.L., Planavsky, N.J., And Johnston, D.T., 2015, Protracted development of bioturbation through the early Palaeozoic Era: Nature Geoscience, v. 8, p. 865-869.

TOOMEY, D.F. AND NITECKI, M. N., 1979, Organic buildups in the Lower Ordovician (Canadian) of Texas and Oklahoma: Fieldiana Geology, New Series, v. 2, p. 1-181.

WALKER, K.R., ShANMUGAM, G., AND RuPPEL, S.C., 1983, A model for carbonate to terrigenous clastic sequences: Geological Society of America Bulletin, v. 94, p. 700-712.

Wedding, L.M., LePCZYK, C.A., PitTman, S.J., Friedlander, A.M., And Jorgensen, S., 2011, Quantifying seascape structure: extending terrestrial spatial pattern metrics to the marine realm: Marine Ecology Progress Series, v. 427, p. 219-232.

Williams, S.H., BoYCE, W.D., AND JAMES, N.P., 1987, Graptolites from the Lower-Middle Ordovician St. George and Table Head groups, western Newfoundland, and their correlation with trilobite, brachiopod, and conodont zones: Canadian Journal of Earth Sciences, v. 24, p. 456-470.

Zarnetske, P.L., Baiser, B., Strecker, A., Record, S., Belmaker, J., ANd Tuanmu, M.-N., 2017, The interplay between landscape structure and biotic interactions: Current Landscape Ecology Reports, v. 2, p. 12-29.

ZHANG, S. AND BARNES, C.R., 2004, Arenigian (Early Ordovician) sea-level history and the response of conodont communities, western Newfoundland: Canadian Journal of Earth Sciences, v. 41, p. 843-865.

Received 29 May 2020; accepted 4 November 2020.

FIG. 1.-Location of the eight study locations in North America (marked with star): Ibex area, Millard County, Utah, USA (locations 3-5); Mingan Island, Quebec, Canada (locations 7-8); western Newfoundland (W. Nfdl), Canada (locations 1-2, 6). See text for further details.

FIG. 2.-Stratigraphic scheme of Early-Middle Ordovician strata of the eight study locations and reef horizons. Abbreviations: F = Île du Fantôme reefs; Fm = Formation; FP = Île de la Fausse Passe reefs; $\mathrm{GH}=$ Green Head reefs; $\mathrm{H}=$ section $\mathrm{H}$; $\mathrm{J}=$ near section $\mathrm{J}$; Lst = limestone; $\mathrm{Mbr}=$ Member; Myr = Million years; R. $=$ Rossodus $; \mathrm{SC}=$ Ship Cove reefs; thr. $=$ thrombolitic $; \mathrm{TP}=$ Table Point reefs. Members of the Fillmore Formation: blf = basal ledge forming limestone member; bsal = brown slope and ledge member; $\mathrm{Ccs}=$ Calathium calcisiltite member; $\operatorname{lglf}=$ light gray ledge forming member; sfss = slope-forming shaly siltstone member. Compiled from Knight et al. (2007), Lavoie et al. (2012), Lindskog et al. (2017), Normore et al. (2018), Ross et al. (1997).

FIG. 3.-Geographic point pattern of recorded reef center coordinates (points) at study locations 38 , and related observation windows (shaded areas). Maps reflect outcrop situation such as topography and strike and dip of reef horizons at each locality (Loc.). Individual reef center coordinates could not be recorded at study locations 1-2 (Ship Cove, Green Head) because at these locations the reefs form expansive coalescent sheets. $n=$ number of reef cores (points). See text for further details. 
FIG. 4.-Outcrop appearance of the eight study locations with sponge-rich Early-Lower Ordovician reefs. A) Digitate thrombolite reef with basal horizon (arrow) of recrystallized archaeoscyphid? sponges; Watts Bight Formation, Tremadocian; Ship Cove location, Port au Port Peninsula, western Newfoundland. B) Maceriate thrombolitic reefs (left) and cross bedded peloidal grainstone (right); Watts Bight Formation, Tremadocian; Green Head location, Port au Port Peninsula, western Newfoundland. C) Calathid-rich patch reef, Church reef horizon; Fillmore Formation, Tremadocian; Pyramid section, Millard County, Utah. D) Sponge-rich patch reef with grainstone flank (arrow), unnamed reef horizon; upper calcarenite member, Fillmore Formation, Floian; H section, Millard County, Utah. E) Calathid-rich reef; H reef horizon, Fillmore Formation, Floian; section H, Millard County, Utah. F) Sponge-rich reefs of upper reef horizon in Wah Wah Formation, Floian; near section J, Millard County, Utah. G) Sponge rich reef; Table Point Formation, Darriwilian; Point Riche, Point Riche Peninsula, western Newfoundland. H) Spongerich reef; Mingan Formation, Darriwilian; Île du Fantôme, Mingan Islands, Quebec. Hatched line marks reef outline.

FIG. 5.- Lithological reconstruction of Green Head reef complex, Watts Bight Formation, Tremadocian; Green Head, Green Head location, Port au Port Peninsula, western Newfoundland. For explanation of reef lithologies (reef lith.) see text. Abbreviations: bioturb. = bioturbated; trunc. surface $=$ truncation or erosional surface; $\mathrm{x}$-bedded $=$ cross bedded.

FIG. 6.-Thin sections of lithology 1 of Green Head reef complex, Watts Bight Formation, Tremadocian; Green Head, Green Head location, Port au Port Peninsula, western Newfoundland. A) Partly silicified (si) and dolomitized maceriate area with preserved patches of Renalcis (re) and gravitationally crystal-silt filled fenestral areas (fe). B) Lichenaria-rich area (li) with well-preserved patches of Renalcis, skeletal wackestone with trilobite (tr), and spar filled fenestrae (fe). C) Detail of A with well-preserved Renalcis-texture.

FIG. 7.-Thin sections of Lower-Middle Ordovician sponge-rich reef-core limestone. A) Church reef horizon; Fillmore Formation, Tremadocian; Pyramid section, Millard County, Utah. B) Detail of burrowed skeletal wackestone with keratose sponge remains in burrows; Church reef horizon; Fillmore Formation, Tremadocian. C) Fenestral, burrowed, skeletal wackestone with mesoclottexture; unnamed reef horizon; upper calcarenite member, Fillmore Formation, Floian. D) Boundstone rich in calathids and lithistids, $\mathrm{H}$ reef horizon, Fillmore Formation, Floian. E) Detail of silty burrowed wackestone with sponge, upper reef horizon in Wah Wah Formation, Floian. F) Boundstone rich in lithistids, and burrowed wackestone, upper reef horizon in Wah Wah Formation, Floian. G) Additional aspect, same as F, upper reef horizon in Wah Wah Formation, Floian. Abbreviations: $\mathrm{br}=$ brachiopod; $\mathrm{bu}=$ burrow; $\mathrm{ca}=$ calathid; $\mathrm{ce}=$ keratose sponge; $\mathrm{e}=$ echinoderm; $\mathrm{fe}=$ fenestrae $; \mathrm{g}=$ gastropod $; \mathrm{sp}=$ sponge; $\mathrm{tr}=$ trilobite .

FIG. 8. - Stratigraphy and lithology of section H (partial) with unnamed reef horizons, Fillmore Formation, Floian, Millard County, Utah. Abbreviation: $\mathrm{Fm}=$ formation; $\mathrm{mbr}=$ member. Lithostratigraphy after Hintze (1973), biostratigraphy after Ross et al. (1997).

FIG. 9.- Lithological reconstruction of reefal interval at lowermost Calathium calcisiltite member, Fillmore Formation, Floian (H reef horizon, herein). For explanation of lithologies, see Figure 8. FIG. 10.-Details of stratigraphy and lithology of reef horizons north of section J (Hintze 1973), Wah Wah Formation, Floian, Millard County, Utah. For explanation of lithologies see Figure 8. FIG. 11.-Thin sections of sponge-rich reefs of the Table Point Formation, Darriwilian. A) Reef core with sponge-rich boundstone, and fenestral, and burrowed wackestone; Point Riche, Point Riche Peninsula, western Newfoundland. B) Bryozoan rich reef core, partly silicified, burrowed and fenestral; Table Point, western Newfoundland. C) Detail of fenestral burrowed wackestone and area with skeleton of lithistid sponge; same as A. For a list of abbreviations see Figure 7.

FIG. 12.- Schematic illustration of the three spatio-temporal modes of reef growth distinguished herein. Figures show idealized vertical view of depositional area. See text for explanation. FIG. 13.- Stratigraphy and lithology of episodic thrombolite reef intervals, lower Catoche Formation, Floian, Port au Choix Peninsula, western Newfoundland. 
FIG. 14. - Schematic illustration of different grades of coalescence, agglomeration and dispersal of reefs discussed herein. Figures show idealized horizontal view of depositional area.

FIG. 15.-Frequency distributions of patch sizes of sponge rich Early-Middle Ordovician reefs, from selected locations discussed herein. Patch size is mean of reef length and width.

Abbreviations: $\mathrm{n}=$ number of reefs; Loc. $=$ study location.

FIG. 16.-Frequency distributions of nearest neighbor distances of sponge rich Early-Middle Ordovician reefs, from selected locations discussed herein. Abbreviations: $n=$ number of reefs; Loc. = study location.

\section{TABLE CAPTION}

TABLE 1.-Comparison of key characteristics of Early-Middle Ordovician reef sites. Individual reef centers and corresponding point pattern estimates could not be recorded at study location 1 (Green Head) and 2 (Ship Cove) because at these locations the reefs form expansive coalescent sheets that partly extent across the entire outcrop areas. Rtest, p-value for Clark-Evans test for $\mathrm{H}_{0}$ of complete spatial randomness, bold font marks $\mathrm{p}$ value $<0.05$ and we reject $\mathrm{H}_{0}$. Hyphen marks where not sufficient data for Rtest. Abbreviations: $\mathrm{cqv}=$ coefficient of quartile variation a measure of relative dispersion; nndist $=$ euclidean nearest neighbor distance; loc. $=$ study location; $\mathrm{Nfdl}=$ Newfoundland; I. = islands; $\mathrm{R}=$ Clark-Evans aggregation index, subs. = subsetted. See text for explanation. 

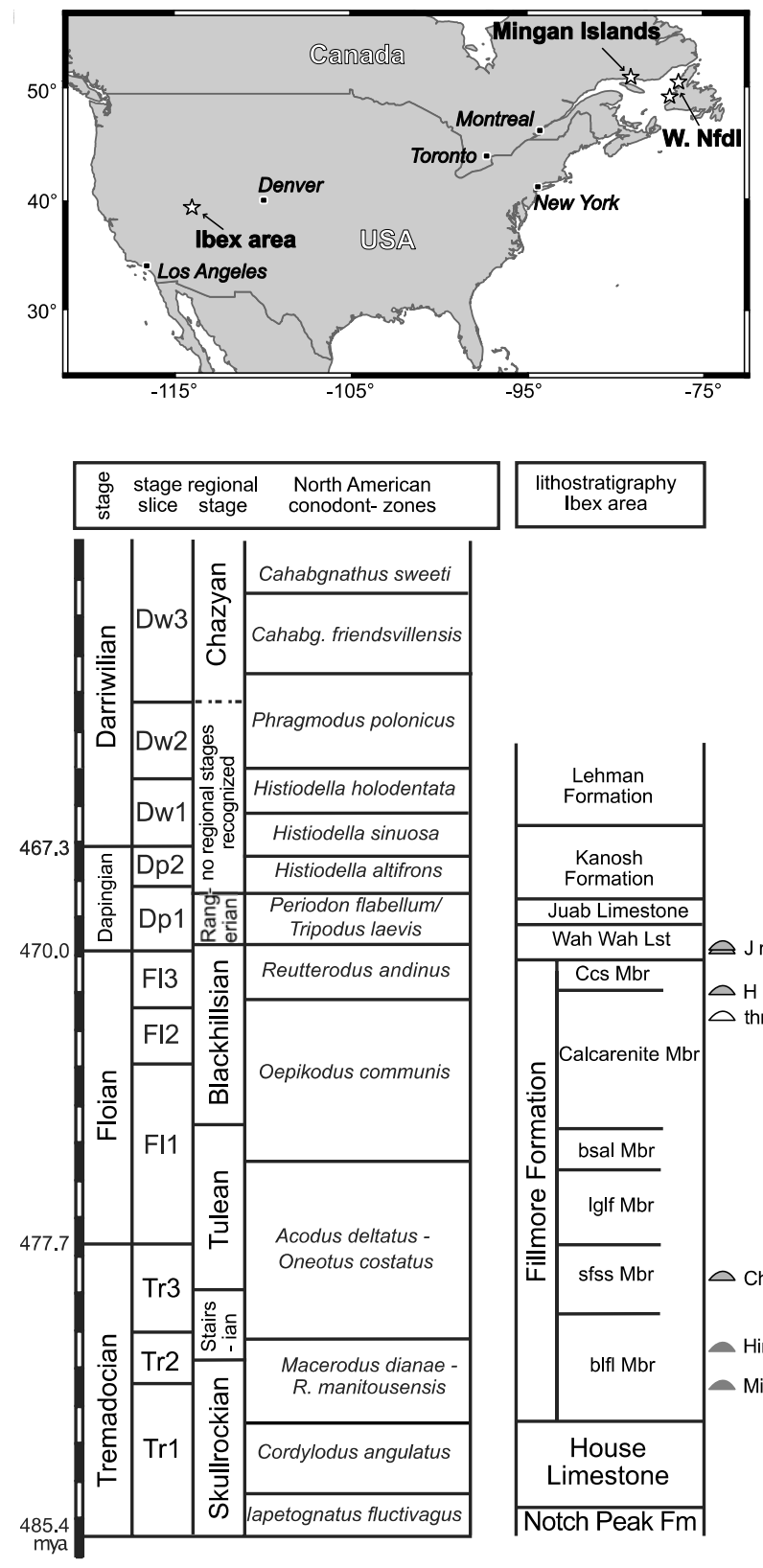

\begin{tabular}{|c|}
\hline $\begin{array}{c}\text { lithostratigraphy } \\
\text { Ibex area }\end{array}$ \\
\hline
\end{tabular}
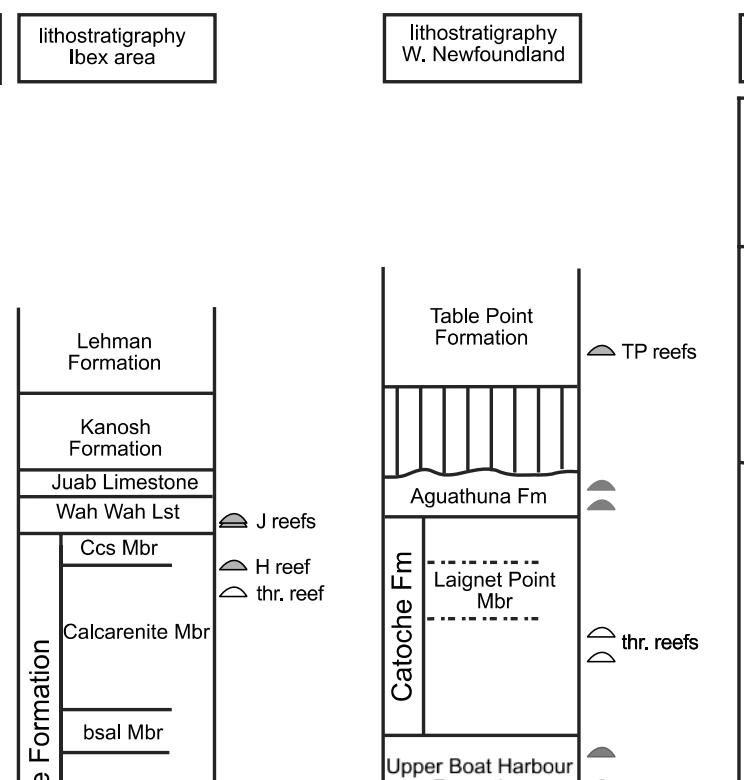

lithostratigraphy Mingan Islands

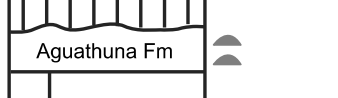

E

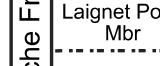
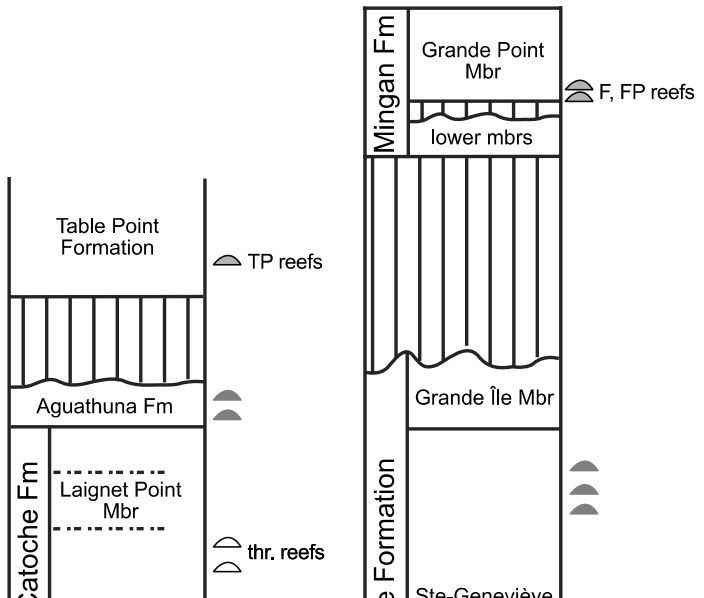

$\circlearrowleft$
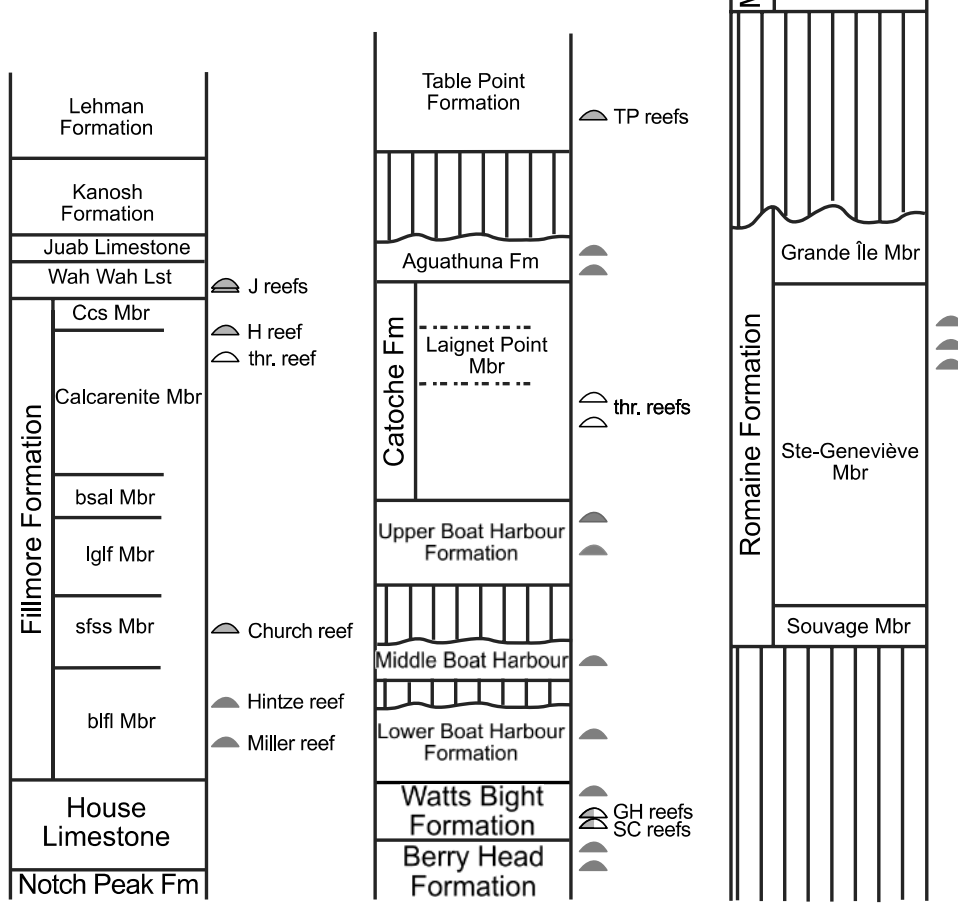

Notch Peak Fm

reefs: $\triangle$ unstudied $\triangle$ thrombolitic $\triangle$ sponge rich 

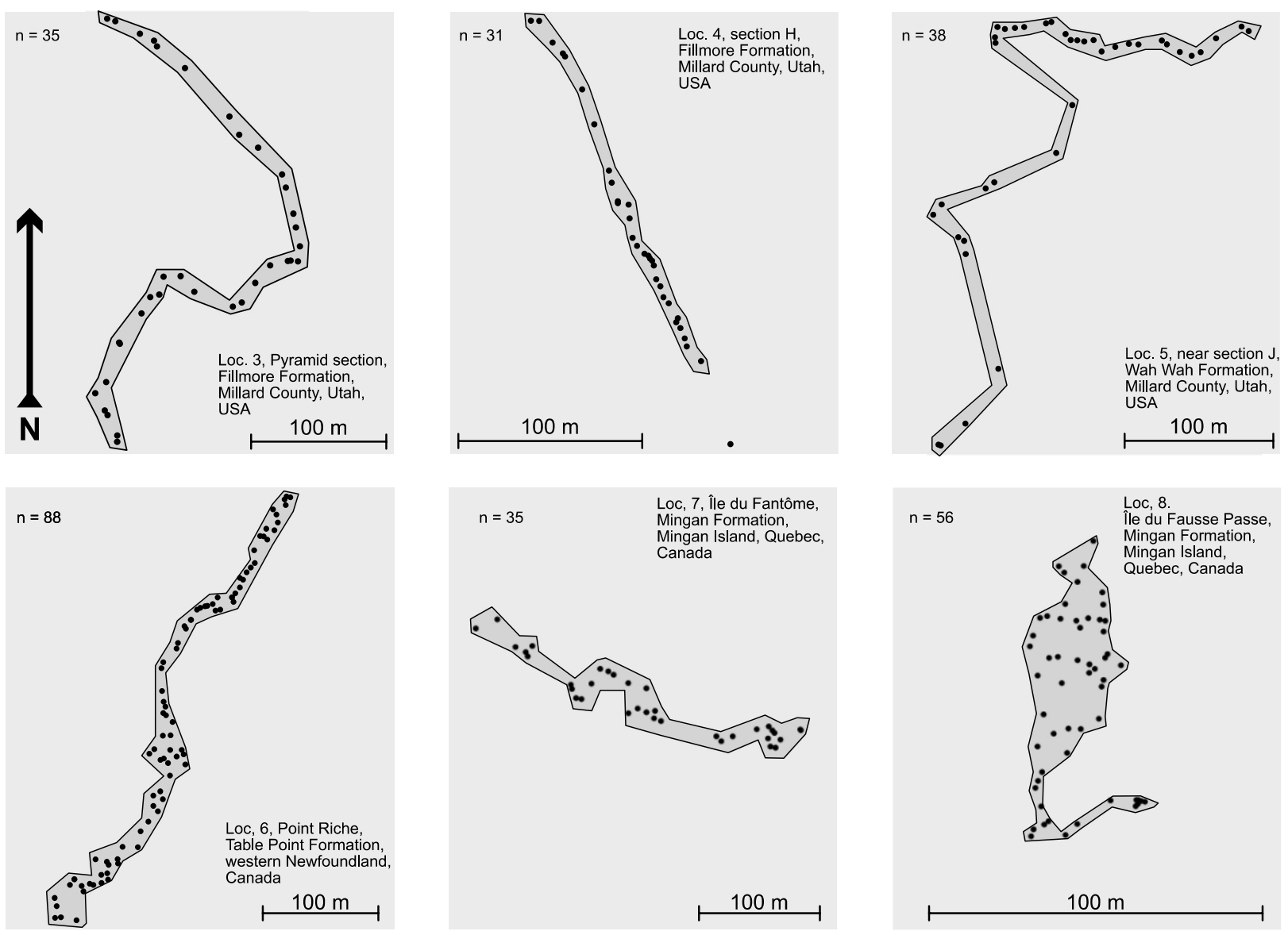

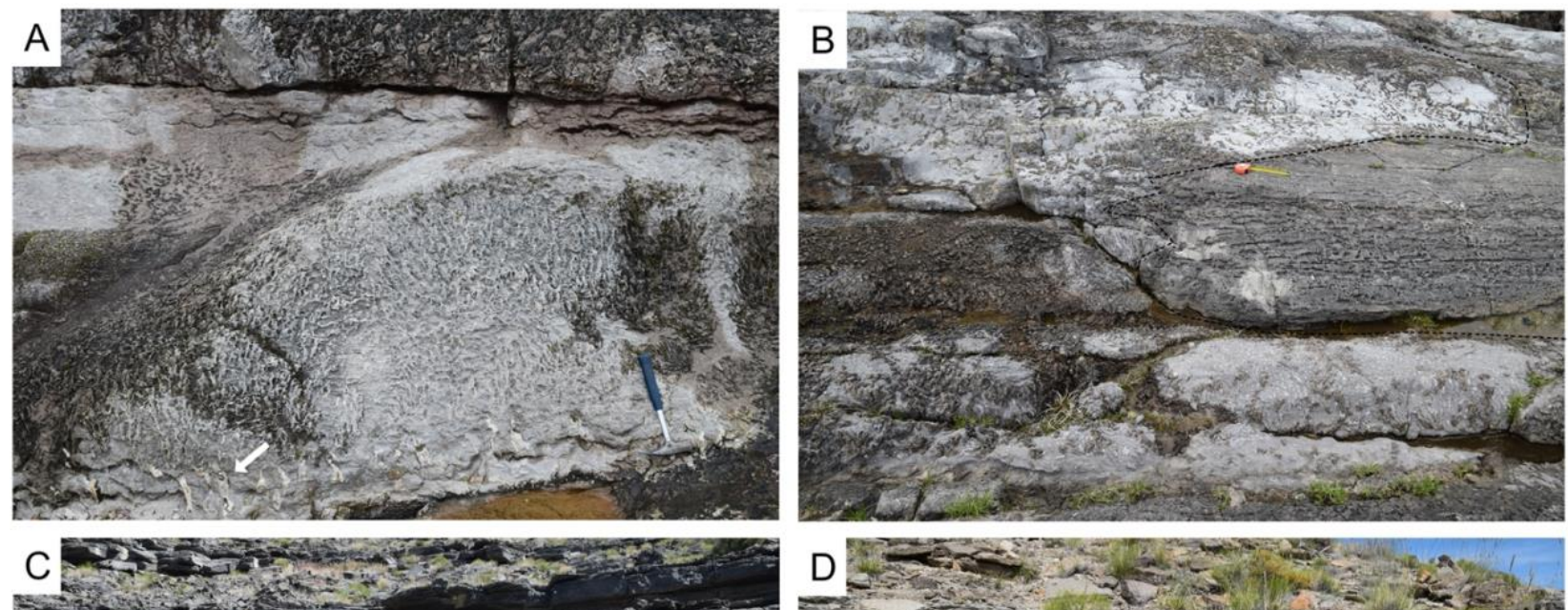

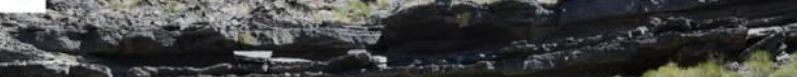
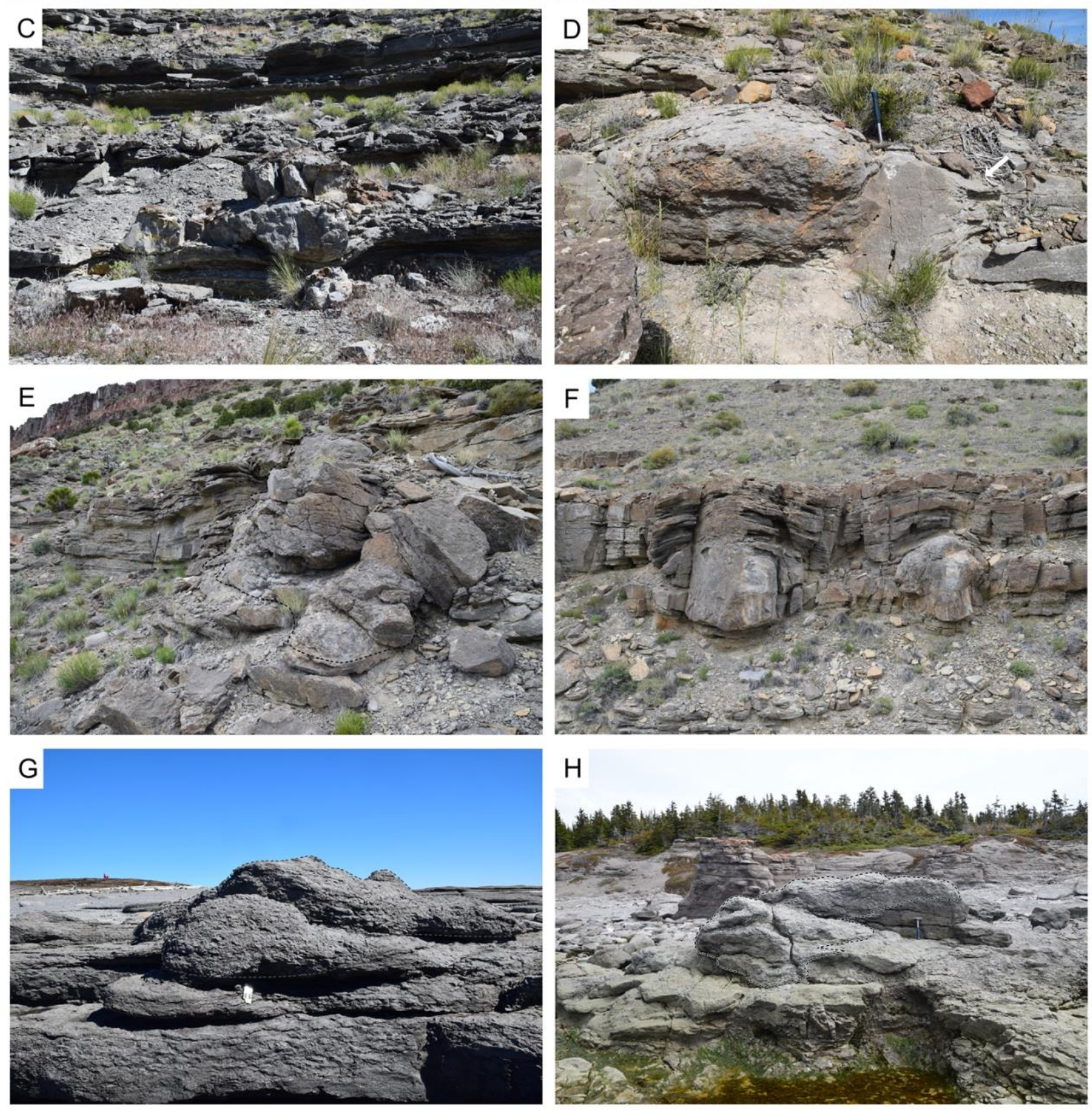

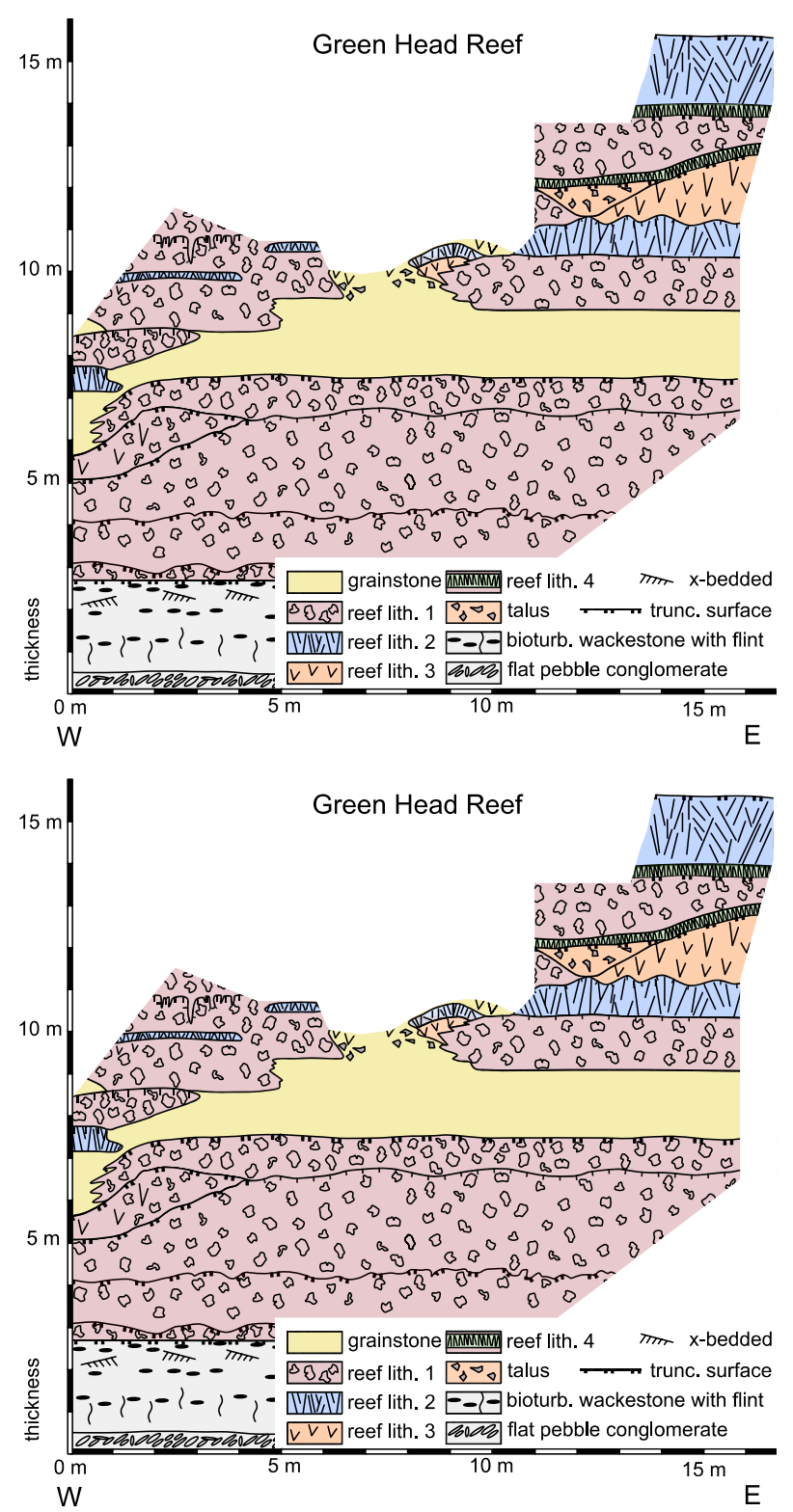

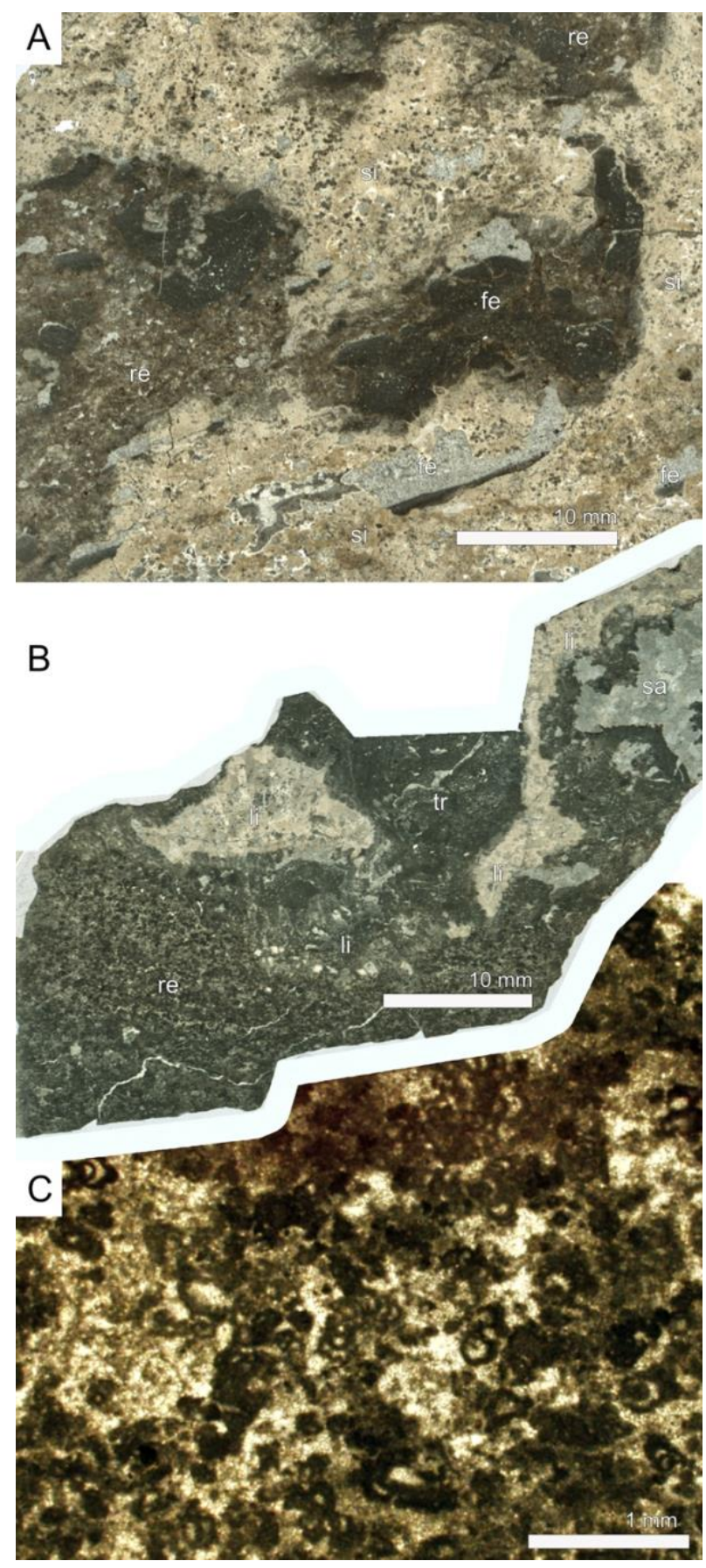

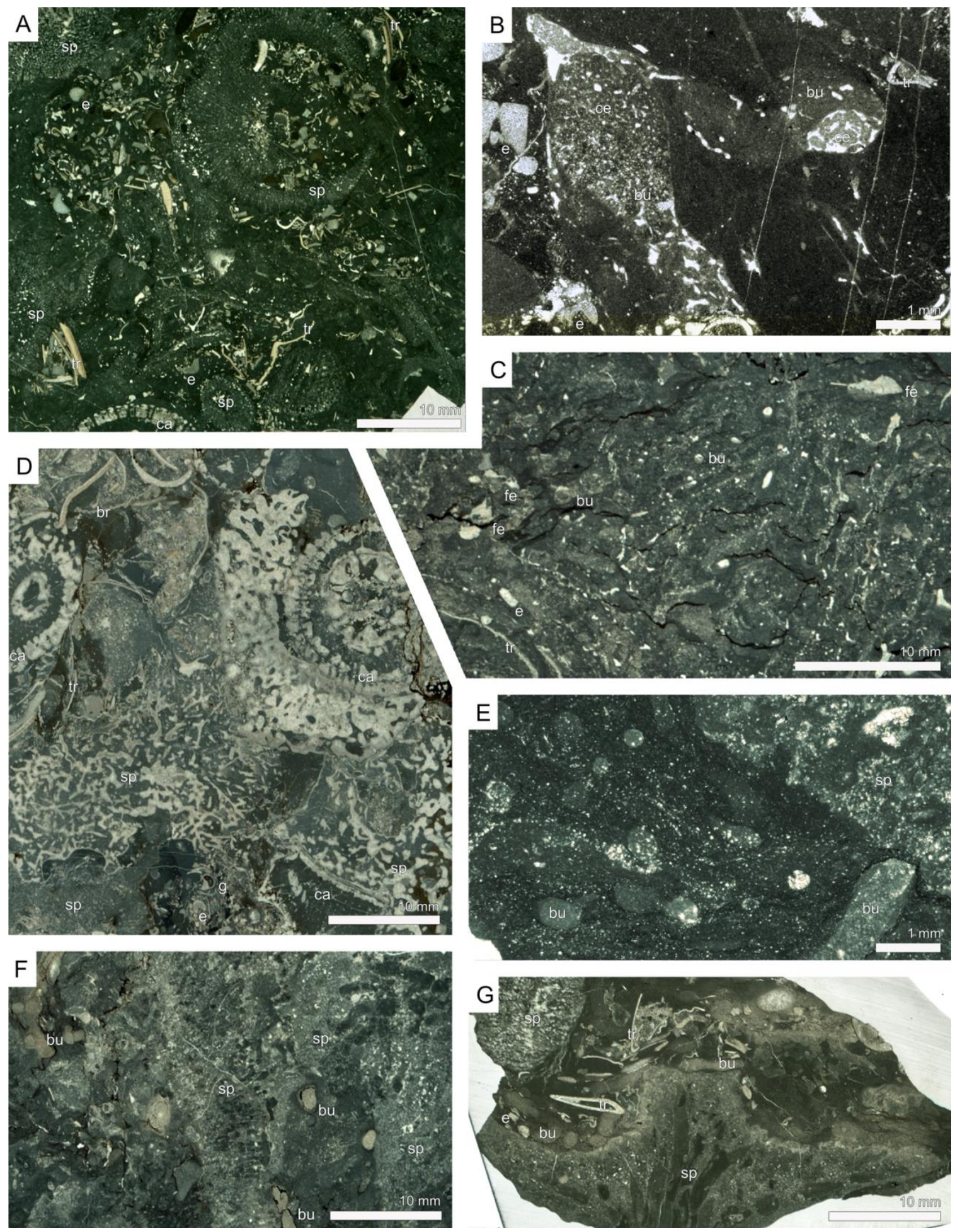


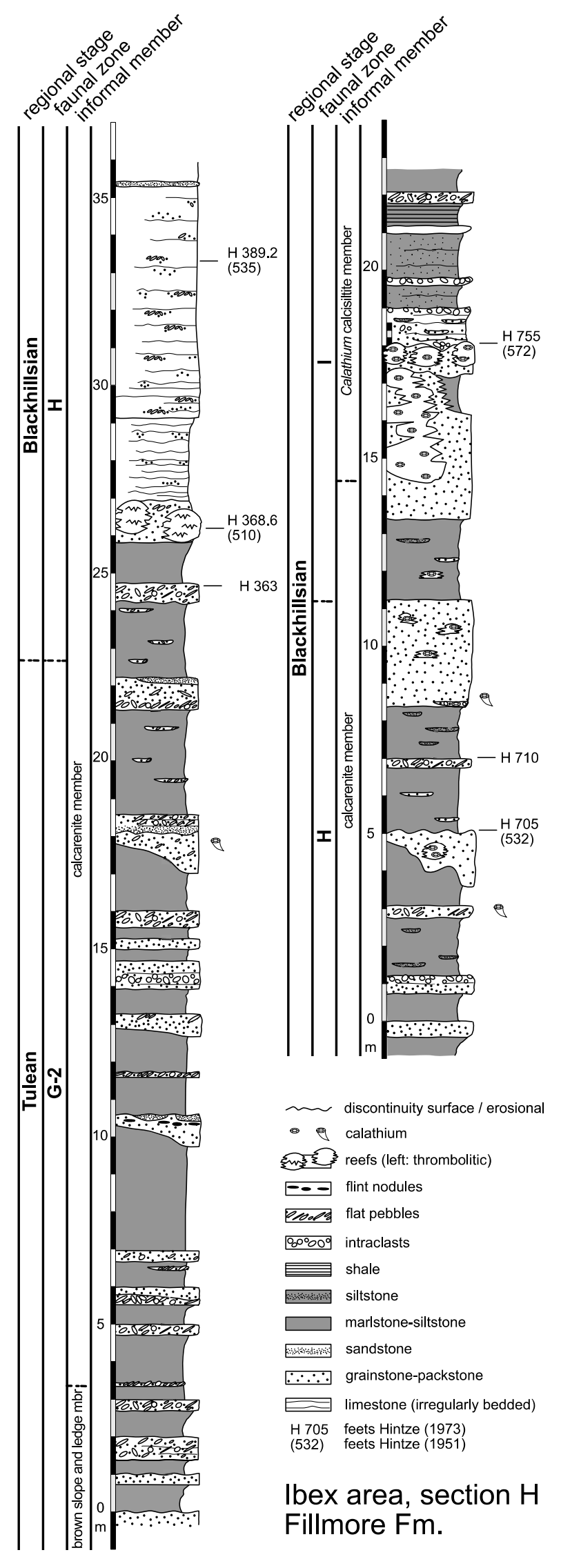



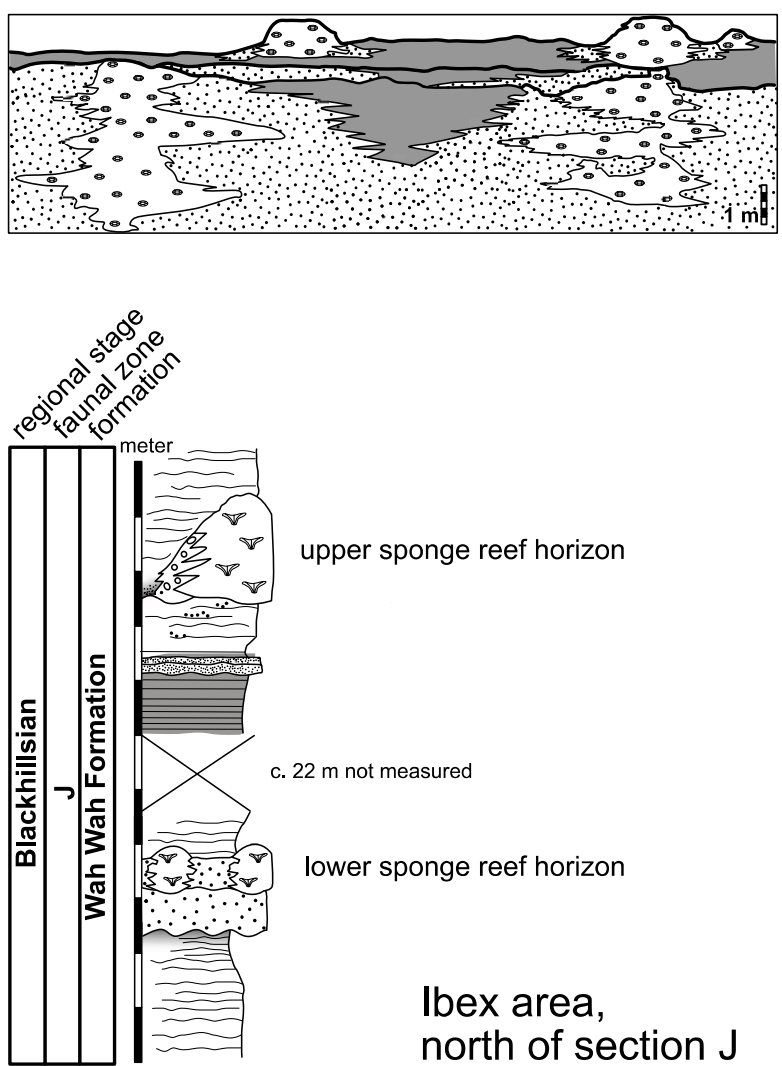

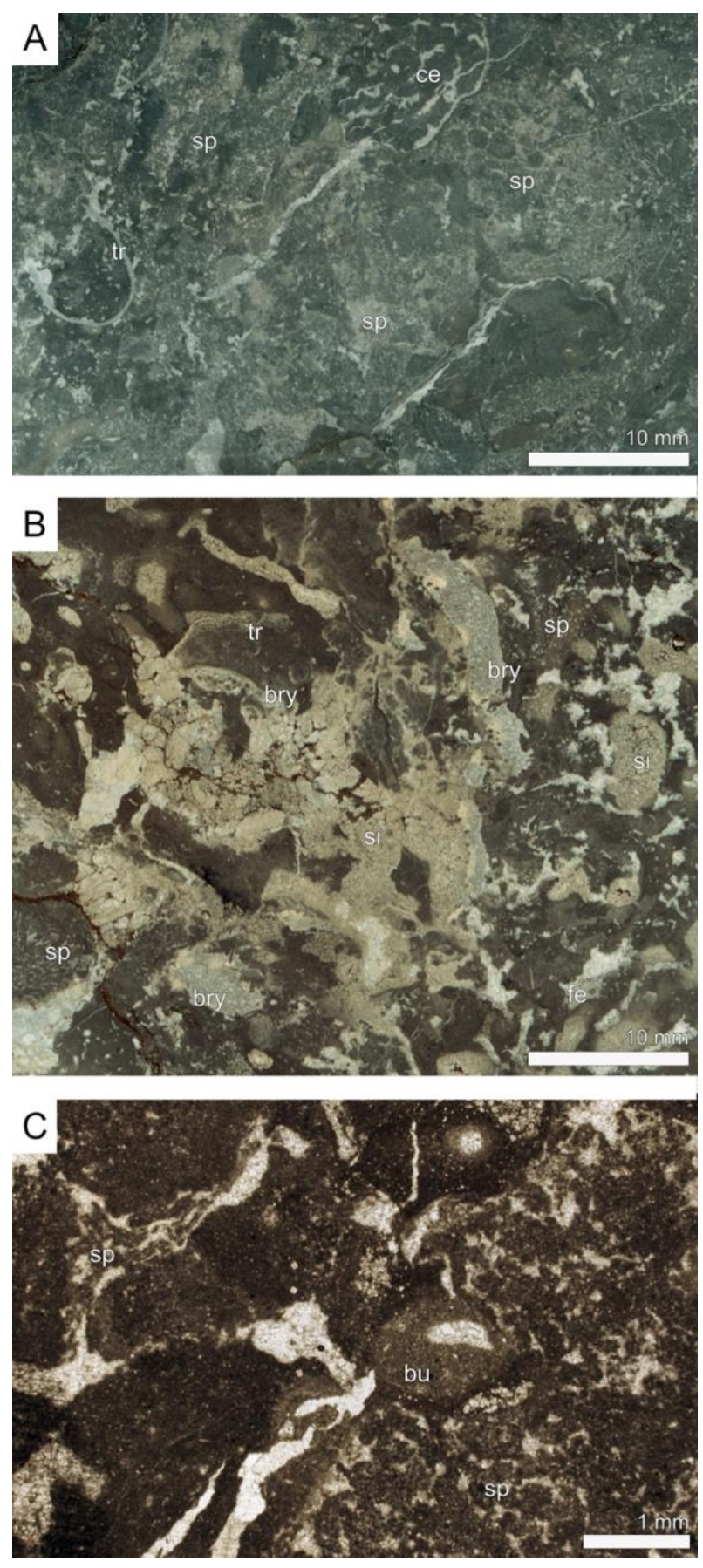

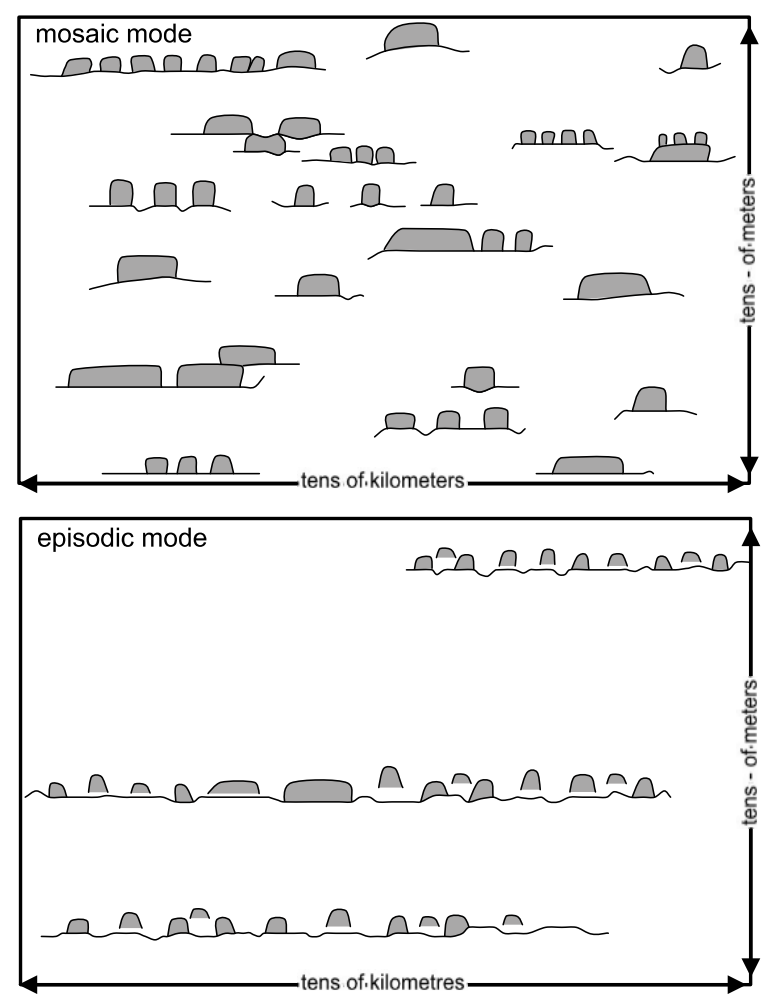

belt and bank mode 


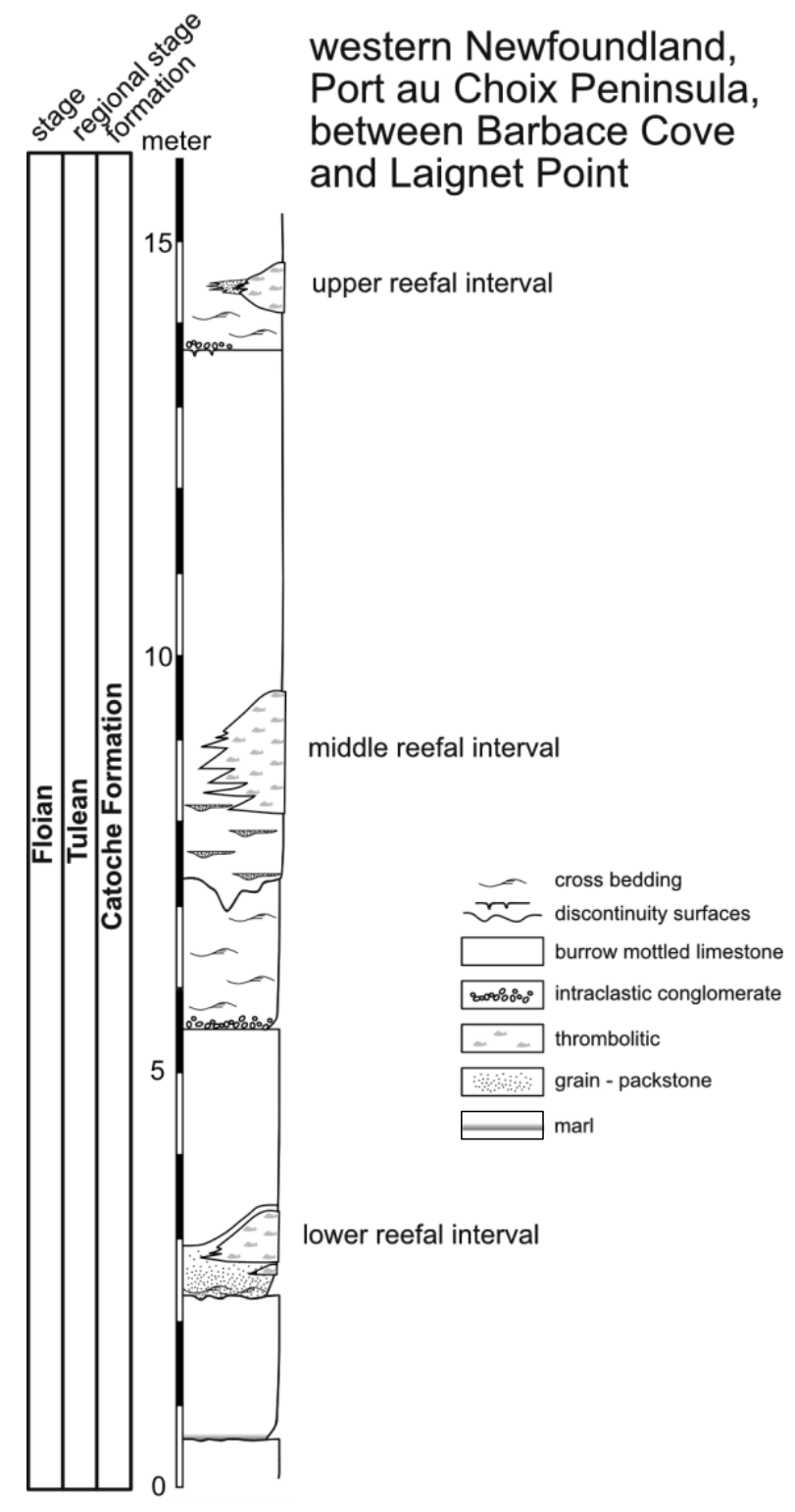



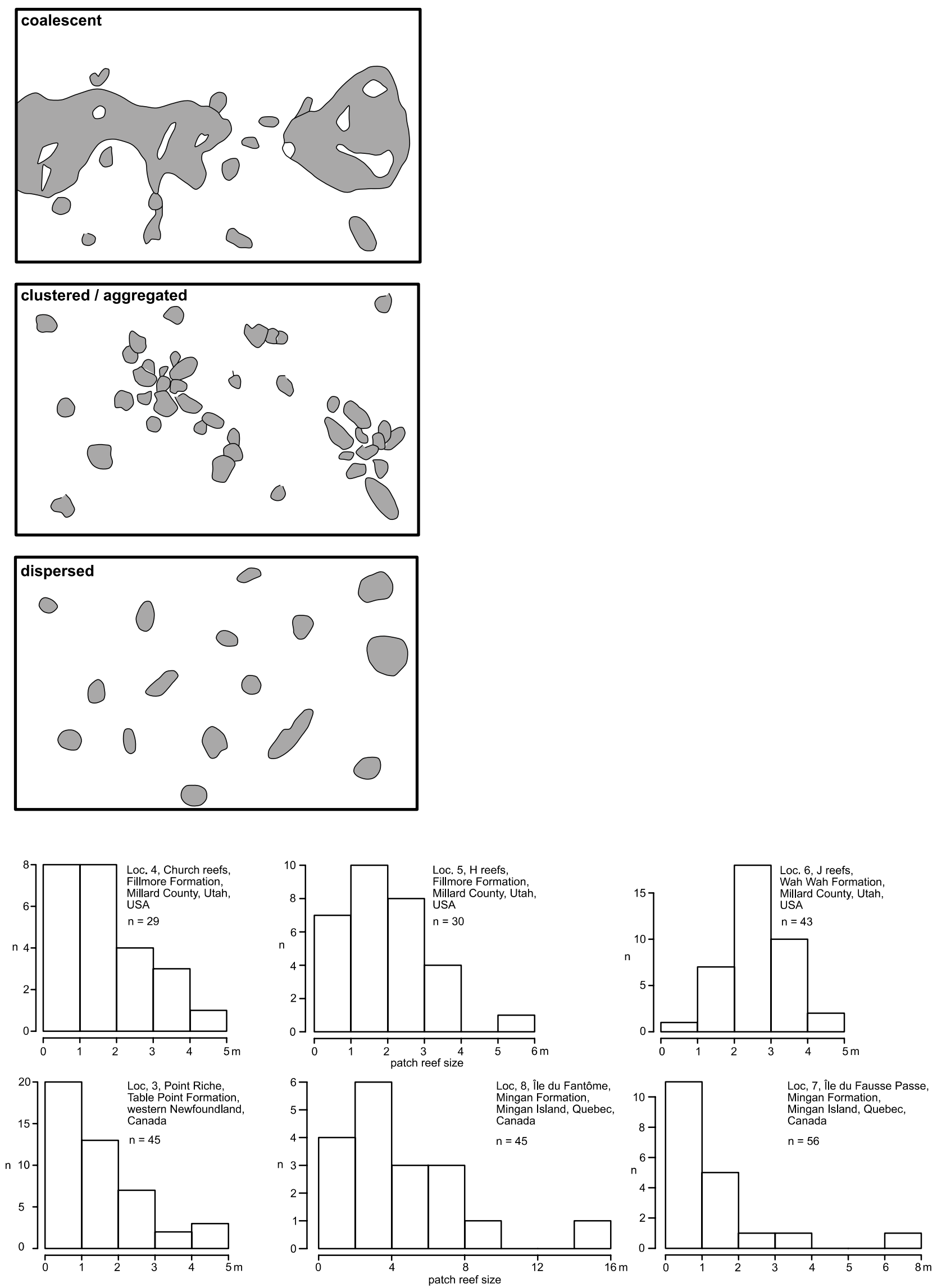

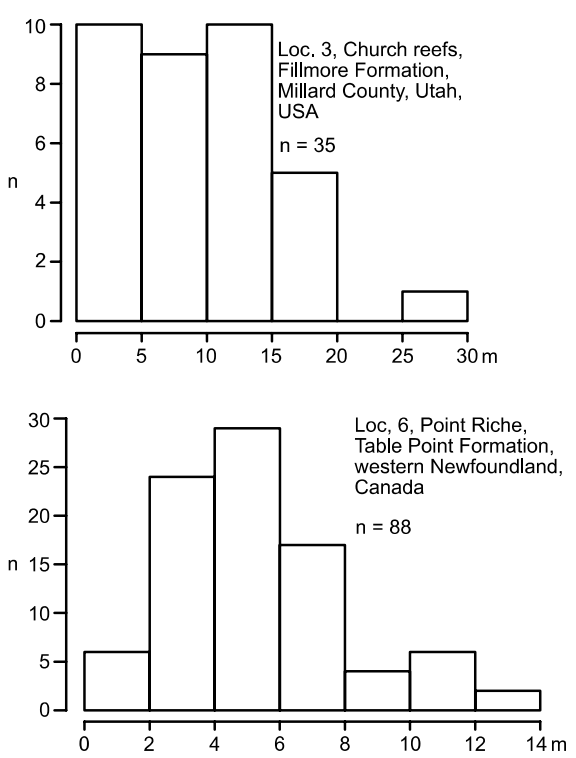
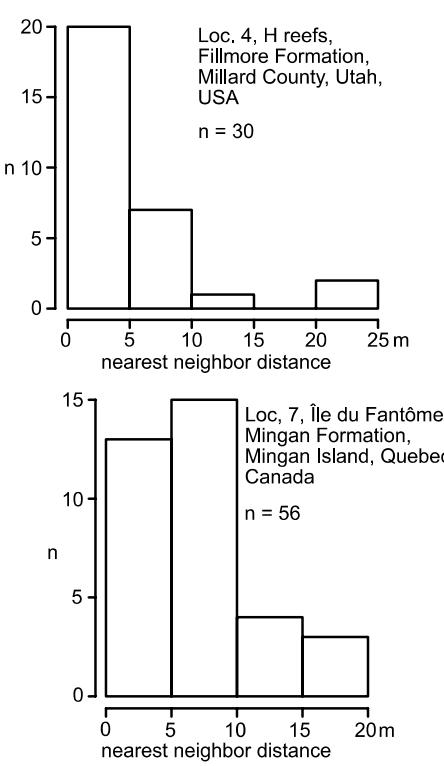
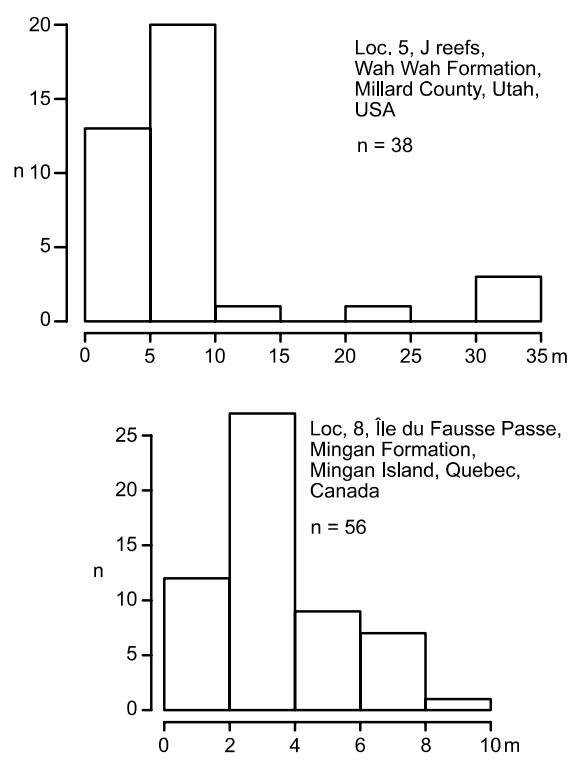